\title{
Novel mononuclear and 1D-polymeric derivatives of lanthanides and (6-benzoic acid)tricarbonylchromium: synthesis, structure and magnetism Dol:
}

10.1039/C6DT04895A

\author{
Document Version \\ Accepted author manuscript
}

Link to publication record in Manchester Research Explorer

Citation for published version (APA):

Gavrikov, A. V., Koroteev, P. S., Efimov, N. N., Dobrokhotova, Z. V., Ilyukhin, A. B., Kostopoulos, A., Ariciu, A-M., \& Novotortsev, V. M. (2017). Novel mononuclear and 1D-polymeric derivatives of lanthanides and (6-benzoic acid)tricarbonylchromium: synthesis, structure and magnetism: synthesis, structure and magnetism. Dalton Transactions, 46(10), 3369-3380. https://doi.org/10.1039/C6DT04895A

\section{Published in:}

Dalton Transactions

\section{Citing this paper}

Please note that where the full-text provided on Manchester Research Explorer is the Author Accepted Manuscript or Proof version this may differ from the final Published version. If citing, it is advised that you check and use the publisher's definitive version.

\section{General rights}

Copyright and moral rights for the publications made accessible in the Research Explorer are retained by the authors and/or other copyright owners and it is a condition of accessing publications that users recognise and abide by the legal requirements associated with these rights.

\section{Takedown policy}

If you believe that this document breaches copyright please refer to the University of Manchester's Takedown Procedures [http://man.ac.uk/04Y6Bo] or contact uml.scholarlycommunications@manchester.ac.uk providing relevant details, so we can investigate your claim.

\section{OPEN ACCESS}




\section{Tran
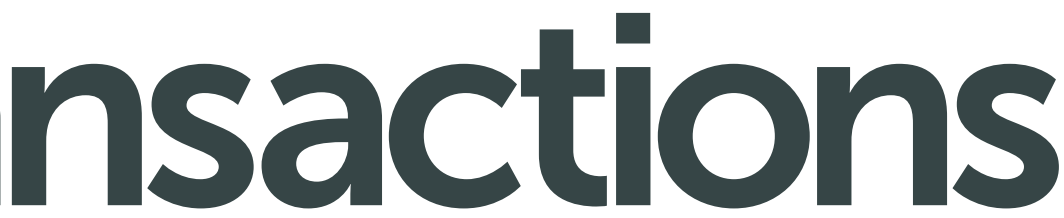

\section{Accepted Manuscript}

This article can be cited before page numbers have been issued, to do this please use: A. V. Gavrikov, P. S. Koroteev, N. Efimov, Z. Dobrohotova, A. B. Ilyukhin, A. Kostopoulos, A. Ariciu and V. M. Novotortsev, Dalton Trans., 2017, DOI: 10.1039/C6DT04895A.

\section{Dalton Transactions}
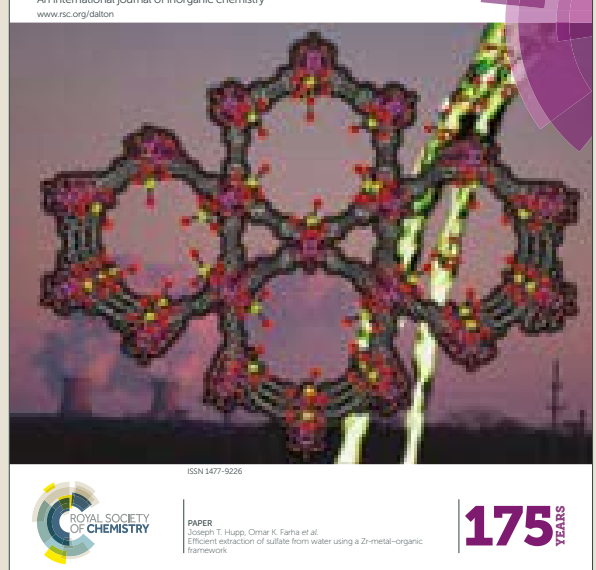

175
This is an Accepted Manuscript, which has been through the Royal Society of Chemistry peer review process and has been accepted for publication.

Accepted Manuscripts are published online shortly after acceptance, before technical editing, formatting and proof reading. Using this free service, authors can make their results available to the community, in citable form, before we publish the edited article. We will replace this Accepted Manuscript with the edited and formatted Advance Article as soon as it is available.

You can find more information about Accepted Manuscripts in the author guidelines.

Please note that technical editing may introduce minor changes to the text and/or graphics, which may alter content. The journal's standard Terms \& Conditions and the ethical guidelines, outlined in our author and reviewer resource centre, still apply. In no event shall the Royal Society of Chemistry be held responsible for any errors or omissions in this Accepted Manuscript or any consequences arising from the use of any information it contains. 


\title{
Journal Name
}

\section{ARTICLE}

Received 00th January 20xx, Accepted 00th January 20xx

DOI: $10.1039 / x 0 x \times 00000 x$

www.rsc.org/

\section{Novel mononuclear and 1D-polymeric derivatives of lanthanides and ( $\eta^{6}$-benzoic acid)tricarbonylchromium: Synthesis, structure and magnetic propertiest}

Andrey Gavrikov, ${ }^{\text {a }}$ Pavel Koroteev, ${ }^{\text {a }}$ Nikolay Efimov, ${ }^{\text {a }}$ Zhanna Dobrokhotova, ${ }^{\text {a }}$ Andrey llyukhin, ${ }^{\text {a }}$ Andreas K. Kostopoulos, ${ }^{b}$ Ana-Maria Ariciu, and Vladimir Novotortsev ${ }^{a}$

\begin{abstract}
Two series of novel heteroleptic derivatives of lanthanides and ( $\eta^{6}$-benzoic acid)tricarbonylchromium (benchrotrenecarboxylic acid) were synthesized and characterized: mononuclear complexes $\left[\operatorname{Ln}(\mathrm{BcrCOO})(\mathrm{acac})_{2}\left(\mathrm{H}_{2} \mathrm{O}\right)_{2}\right](\mathrm{Ln}$ $=\mathrm{Eu}(\mathbf{1}), \mathrm{Gd}(\mathbf{2}), \mathrm{Tb}(\mathbf{3 a}), \mathrm{Dy}(\mathbf{4 a}), \mathrm{Ho}(\mathbf{5 a}))$ and 1D-polymeric ones $\left[\operatorname{Ln}(\mathrm{BcrCOO})(\mathrm{acac})_{2}\left(\mathrm{H}_{2} \mathrm{O}\right)\right]_{n}(\mathrm{Ln}=\mathrm{Tb}(\mathbf{3 b}), \mathrm{Dy}(\mathbf{4 b}), \mathrm{Ho}(\mathbf{5 b})$, $\operatorname{Er}(6), \operatorname{Tm}(7), \mathrm{Yb}(8)$ and $\mathrm{Y}(9)), \mathrm{Bcr}=\left(\eta^{6}-\mathrm{C}_{6} \mathrm{H}_{5}\right) \mathrm{Cr}(\mathrm{CO})_{3}$. The molecular and crystal structures of the obtained compounds were determined. Complexes $\mathbf{3 a}, \mathbf{4 a}, \mathbf{4 b}, \mathbf{6}$ and $\mathbf{8}$ were found to possess SMM properties. Two maxima were observed on $\chi^{\prime \prime}(v)$ dependencies (LF and HF) for $\mathbf{4 a}, \mathbf{4 b}$ and $\mathbf{6}$. For $\mathbf{4 a}$, the anisotropy barriers are $\Delta_{\text {eff }} / \mathrm{k}_{\mathrm{B}}=100 \mathrm{~K}$ and $118 \mathrm{~K}$ in zero dc-field ( $128 \mathrm{~K}$ and $143 \mathrm{~K}$ in $2000 \mathrm{Oe}$ field) for the LF (low frequency) and HF (high frequency) signals, respectively. These values are ones of the highest for Ln carboxylate complexes. The nature of appearance of two maxima in the system was discussed.
\end{abstract}

\section{Introduction}

Currently, there is a considerable interest in directed design, synthesis and comprehensive investigation of lanthanidebased coordination compounds of various dimensions as well as supramolecular systems. ${ }^{1}$ This is highly due to their interesting magnetic ${ }^{2}$ and luminescent ${ }^{3}$ properties, and thus to ability to serve as a basis of various functional materials. ${ }^{4}$

Among such compounds, carboxylate derivatives are of special interest. These complexes exhibit a great structural diversity due to the capability of the carboxy groups to manifest various structural features. ${ }^{5}$ Indeed, a wide range of ${\text { bi }-{ }^{6} \text { oligonuclear }}^{7}$, and polymeric ${ }^{8}$ lanthanide carboxylate complexes are known. Mononuclear Ln carboxylates are also reported ${ }^{9}$ but examples of such compounds are scarce.

There is a special group of Ln carboxylate complexes which contain stable organometallic derivatives as substituents in the acid moiety. A few known examples of such compounds include derivatives of ferrocene (bis $\left(\eta^{5}\right.$-cyclopentadienyl)iron, $\left.\left(\eta^{5}-\mathrm{C}_{5} \mathrm{H}_{5}\right)_{2} \mathrm{Fe}\right)^{10-12}$ and cymantrene $\left(\eta^{5}-\right.$ cyclopentadienyltricarbonylmanganese, $\left.\left(\eta^{5}-\mathrm{C}_{5} \mathrm{H}_{5}\right) \mathrm{Mn}(\mathrm{CO})_{3}\right) .{ }^{13}$ Presence of the transition metal bound to an aromatic $\pi$ system allows to regard these complexes either as typica

\footnotetext{
N.S. Kurnakov Institute of General and Inorganic Chemistry, Russian Academy of Sciences, Leninsky prosp. 31, 119991 Moscow, Russian Federation

${ }^{b}$ School of Chemistry and Photon Science Institute, The University of Manchester, Manchester, M13 9PL, United Kingdom

+ Electronic Supplementary Information (ESI) available: [details of any supplementary information available should be included here]. See DOI: 10.1039/x0xx00000x
}

lanthanide carboxylates or as heterometallic $3 d-4 f-$ compounds. Therefore, it may be expected that these complexes would manifest properties typical for Ln compounds, e.g. single-molecule magnet (SMM) properties (in case of heavy lanthanides, i.e., $\mathrm{Tb}-\mathrm{Yb}$ ), while their thermolysis should resemble that of classical heterometallic $3 d$-4f-complexes, i.e. result in formation of corresponding complex oxides, Ln manganites and ferrites.

In the past decade, only lanthanide carboxylates containing the ferrocene moiety have been reported. This group includes complexes with ferrocenemono- and dicarboxylic acids, ${ }^{10} p$ ferrocenylbenzoic acid $^{11}$ and $\beta$-ferrocenoylpropionic acid. ${ }^{12}$ The first structurally characterized lanthanide complexes were assembled on a basis of 1,1'-ferrocenedicarboxylic acid ( $\left.\mathrm{H}_{2} \mathrm{Fcdc}\right)$ namely, 2D-polymeric complexes $\left[\mathrm{Ln}_{2}(\mathrm{Fcdc})_{3}\left(\mathrm{H}_{2} \mathrm{O}\right)_{4}\right]_{n} \cdot n \mathrm{H}_{2} \mathrm{O}(\mathrm{Ln}=\mathrm{Eu}, \mathrm{Sm})$ which consist of $\mathrm{Ln}^{3+}$ ions, bridging $\mathrm{Fcdc}^{2-}$ moieties, and aqua ligands. ${ }^{10 a, b}$ Layered lanthanide ferrocenedicarboxylate polymers $\left\{\left[\mathrm{Ln}\left(\mathrm{n}^{2}-\mathrm{O}_{2} \mathrm{CFCCO}_{2}\right.\right.\right.$ $\left.\left.\left.\eta^{2}\right)\left(\mu_{2}-\eta^{2}-\mathrm{O}_{2} \mathrm{CFCCO}_{2}-\eta^{2}-\mu_{2}\right)_{0.5}\left(\mathrm{H}_{2} \mathrm{O}\right)_{2}\right] \cdot m \mathrm{H}_{2} \mathrm{O}\right\}_{n} \quad(\mathrm{Ln}=\mathrm{Eu}, \mathrm{Tb}, m=2$; $\left.\mathrm{Fc}=\left(\eta^{5}-\mathrm{C}_{5} \mathrm{H}_{5}\right)\left(\eta^{5}-\mathrm{C}_{5} \mathrm{H}_{4}\right) \mathrm{Fe}\right)$ have also been synthesized ${ }^{10 \mathrm{c}}$ along with isostructural binuclear derivatives of ferrocenecarboxylic acid $\left[\mathrm{Ln}_{2}(\mathrm{FcCOO})_{6}\left(\mathrm{CH}_{3} \mathrm{OH}\right)_{x}\left(\mathrm{H}_{2} \mathrm{O}\right)_{1-x}\right] \cdot x \mathrm{H}_{2} \mathrm{O},(\mathrm{Ln}=\mathrm{La}, \mathrm{Nd}, \mathrm{Eu}, \mathrm{Gd})$, where the $\mathrm{Ln}$ atoms are linked via two chelate-bridging $\mathrm{FcCOO}$ ligands, and the other four ferrocenecarboxylate moieties are coordinated in a bidentate chelate fashion. ${ }^{10 d, e}$ Modifying of the synthetic procedure allowed Liu et al. ${ }^{10 \mathrm{f}}$ to obtain binuclear $\left[\mathrm{Er}_{2}\left(\mu_{2}-\mathrm{OOCFc}\right)_{2}\left(\eta^{2}-\mathrm{OOCFc}\right)_{2}\left(\eta^{1}-\mathrm{OOCFc}\right)_{2}(\mathrm{MeOH})_{2}\left(\mathrm{H}_{2} \mathrm{O}\right)_{2}\right]$ complex with the different coordination modes of $\mathrm{FcCOO}$, namely, tridentate chelate-bridging, bidentate chelate and monodentate ones. All binuclear structures under consideration are built similarly, in all of the cases the $\mathrm{Ln}^{3+}$ ions 
are linked via two chelate-bridging carboxylates. Binuclear moieties can also be distinguished in the structures of lanthanide derivatives of 1,1'-ferrocenedicarboxylic acid which are coordination polymers; in all cases, the $\mathrm{Ln}^{3+}$ ions are also linked via two chelate-bridging carboxylates. New heteroleptic lanthanide ferrocenecarboxylates, $\left[\operatorname{Ln}_{2}\left(\mu-O, \eta^{2}-\mathrm{OOCFC}\right)_{2}\left(\mu_{2-}\right.\right.$ $\left.\left.\mathrm{O}, \mathrm{O}^{\prime}-\mathrm{OOCFC}\right)_{2}\left(\eta^{2}-\mathrm{NO}_{3}\right)_{2}(\mathrm{DMSO})_{4}\right] \quad(\mathrm{Ln}=\mathrm{Gd}, \mathrm{Tb}, \mathrm{Y})$, were obtained and characterized by XRD. ${ }^{10 \mathrm{~g}}$ Unlike the previously known Ln ferrocenecarboxylates, ${ }^{10 a-g}$ the $\mathrm{Ln}^{3+}$ ions in these isostructural complexes are bound via two bridging and two chelate-bridging carboxylate ligands. The magnetic behavior and thermal decomposition of the complexes with $\mathrm{Ln}=\mathrm{Gd}$, Tb were studied, and decomposition products were shown to contain garnets $\mathrm{Ln}_{3} \mathrm{Fe}_{5} \mathrm{O}_{12}$.

No information on cymantrenecarboxylate complexes and their physicochemical properties was available before our publications. $^{7 a, 13}$ Both binuclear complexes typical of lanthanide carboxylates $^{7 \mathrm{a}, 13 a-c}$ and 1D-polymeric complexes $^{8 a, 13 e, f}$ were obtained. Varying of the synthesis conditions and usage of auxiliary ligands made it possible to change gradually the $\mathrm{Mn}: \mathrm{Ln}$ ratio in the molecules of the compounds, and to obtain it equal to $3: 1^{13 a-c}, 2: 1^{7 a, 8 a}$ and $1: 1{ }^{13 e}$ This allowed to use various cymantrenecarboxylate complexes of lanthanides as precursors for pure manganites $\mathrm{LnMn}_{2} \mathrm{O}_{5}$ or $\mathrm{LnMnO}_{3}$ exhibiting multiferroic properties. It should be noted that combination of the catalytic properties of the cymantrenyl moiety and of $\mathrm{Ln}^{3+}$ ions opened prospects for application of lanthanide cymantrenecarboxylates as catalysts for stereoregular polymerization of diene hydrocarbons. ${ }^{13 \mathrm{C}}$ It has also been shown that Dy cymantrenecarboxylates manifest SMM properties. ${ }^{13 d, f}$

Benchrotrene $\quad\left(\left(\eta^{6}\right.\right.$-benzene)tricarbonylchromium, $\quad\left(\eta^{6}\right.$ $\left.\left.\mathrm{C}_{6} \mathrm{H}_{6}\right) \mathrm{Cr}(\mathrm{CO})_{3}\right)$ is an electron analogue of cymantrene their structures are also similar (piano stool type). Therefore, the ability of formation of lanthanide benchrotrenecarboxylates similar to corresponding cymantrenecarboxylates can be assumed. However, for benchrotrene-based carboxylic acids, there are only few known complexes with alkali and transition metals, and studies of them are mainly focused on structural matters. ${ }^{14,15}$ The study ${ }^{15}$ reports the preparation and detailed structural study of compounds based on organic derivatives of tin and benchrotrenecarboxylic acid $\left(\left(\eta^{6}\right.\right.$-benzoic acid)tricarbonylchromium) and thus is of great interest. It is worth mentioning that no lanthanide benchrotrenecarboxylates are known to date.

This paper develops a previously reported $^{13 e}$ novel approach to the synthesis of heteroleptic lanthanide carboxylate complexes. Synthesis and investigation of two series of novel derivatives of lanthanides and benchrotrenecarboxylic acid BcrCOOH $\left(\mathrm{Bcr}=\left(\eta^{6}-\mathrm{C}_{6} \mathrm{H}_{5}\right) \mathrm{Cr}(\mathrm{CO})_{3}\right)$, namely, the mononuclear complexes $\left[\mathrm{Ln}(\mathrm{BcrCOO})(\mathrm{acac})_{2}\left(\mathrm{H}_{2} \mathrm{O}\right)_{2}\right]$ and the 1D-polymeric $\left[\mathrm{Ln}(\mathrm{BcrCOO})(\mathrm{acac})_{2}\left(\mathrm{H}_{2} \mathrm{O}\right)\right]_{n}$ ones, are reported.

\section{Experimental}

Materials and physical methods
The following commercial reagents and solvents were used for the syntheses: hydrated lanthanide acetylacetonates, $\mathrm{Ln}(\mathrm{acac})_{3} \cdot 3 \mathrm{H}_{2} \mathrm{O},\left(\eta^{6}\right.$-methylbenzoate)tricarbonylchromium and solvents (EtOH, 'PrOH, THF) from Alfa Aesar. Benchrotrenecarboxylic acid was synthesized by alkali hydrolysis of $\left(\eta^{6}\right.$-methylbenzoate)tricarbonylchromium according to a known procedure. ${ }^{16}$ Before use in the synthesis, it was dried in a vacuum desiccator. All experiments with the reaction mixtures were carried out in foil-wrapped vessels to prevent photolysis. All solvents were used without further purification.

Elemental analysis was carried out using an EA1108 85 automatic $\mathrm{C}, \mathrm{H}, \mathrm{N}, \mathrm{S}$ analyzer (Carlo Erba Instruments). Attenuated total reflection infrared (ATR-IR) spectra were recorded in the range of $400-4000 \mathrm{~cm}^{-1}$ using a Bruker ALPHA instrument.

Magnetic susceptibility measurements were performed with a Quantum Design SQUID magnetometer MPMS-XL and a Quantum Design susceptometer PPMS-9. These instruments work between 1.8 and $400 \mathrm{~K}$ for dc applied fields ranging from -7 to 7 T (MPMS-XL) and -9 to 9 T (PPMS-9), respectively. For ac susceptibility measurements, an oscillating ac field of 1 or 5 Oe with a frequency between 10 and $10000 \mathrm{~Hz}$ (PPMS) and an oscillating field of 1.55 Oe with a frequency between 0.1 and $1500 \mathrm{~Hz}$ (MPMS) were employed. Measurements were performed on polycrystalline samples sealed in a polyethylene bags and covered with mineral oil in order to prevent fieldinduced orientation of the crystallites). The paramagnetic components of the magnetic susceptibility $\chi$ were determined taking into account the diamagnetic contribution evaluated from Pascal's constants as well as the contributions of the sample holder and mineral oil.

The magnetization relaxation times $\tau=1 / 2 \pi v_{\max }$ and $\alpha$ factors, which account for the distribution in the relaxation processes, were obtained by fitting $\chi^{\prime}(v)$ and $\chi^{\prime \prime}(v)$ plots using the generalized Debye model or a linear combination of two Debye models (see SI).

Synthesis of $\left[\operatorname{Ln}(\mathrm{BcrCOO})(\mathrm{acac})_{2}\left(\mathrm{H}_{2} \mathrm{O}\right)_{2}\right](\operatorname{Ln}=\mathrm{Eu}(1), \mathrm{Gd}(2), \mathrm{Tb}(3 \mathrm{a})$, Dy (4a), Ho (5a)).

Complexes $\mathbf{1}$ and $\mathbf{2}$ were synthesized according to the following procedure. Hydrated lanthanides trisacetylacetonates, $\operatorname{Ln}(\mathrm{acac})_{3} \cdot 3 \mathrm{H}_{2} \mathrm{O}(0.68 \mathrm{mmol})$ were dissolved in THF (11 mL). A solution of BcrCOOH (175 mg, $0.68 \mathrm{mmol})$ in ${ }^{i} \mathrm{PrOH}(11 \mathrm{~mL})$ and distilled water $(3 \mathrm{~mL})$ were added successively with stirring to the resulting solutions. The mixtures were refluxed for $\mathbf{2 0} \mathrm{min}$ in a water bath and then slowly concentrated in vacuo using a water-jet pump. After cooling to room temperature, orange crystals suitable for X-ray diffraction precipitated. The yields (based on $\mathrm{BcrCOOH}$ ) were $40-45 \%$. The single-phase state of the samples was confirmed by X-ray powder diffraction.

For 1, anal. calc. for $\mathrm{C}_{20} \mathrm{H}_{23} \mathrm{CrEuO}_{11}$ : C, 37.34; $\mathrm{H}, 3.60$. Found: C, 37.38; $\mathrm{H}, 3.58 \%$.

ATR-IR of 1, cm ${ }^{-1}$ : 3495 br. w, 3076 w, 1958 m, $1896 \mathrm{~s}$, 1868 vs, 1643 w, 1579 s, 1546 s, 1512 s, 1454 m, 1437 m, 1406 
s, 1371 vs, 1265 s, 1198 m, 1158 m sh., 1151 m, 1136 m, 1046 w, $1019 \mathrm{~s}, 944 \mathrm{~m}, 921 \mathrm{~s}, 851 \mathrm{~m}, 828 \mathrm{~m}, 787 \mathrm{~m}, 724 \mathrm{w}, 691 \mathrm{~m}$, $656 \mathrm{~s}, 645 \mathrm{~m}$ sh., $624 \mathrm{~s}, 612 \mathrm{~s}, 565 \mathrm{~m}, 531$ vs, $481 \mathrm{~s}, 447 \mathrm{~s}, 438$ s, $406 \mathrm{~s}$.

For 2, anal. calc. for $\mathrm{C}_{20} \mathrm{H}_{23} \mathrm{CrGdO}_{11}$ : C, 37.03; $\mathrm{H}, 3.57$. Found: C, 37.08; $\mathrm{H}, 3.54 \%$.

ATR-IR of 2, cm ${ }^{-1}$ : 3496 br. w, 3076 w, 1958 m, $1896 \mathrm{~s}$, 1868 vs, 1643 w, 1579 s, 1546 s, 1512 s, 1454 m, 1437 m, 1406 s, 1371 vs, $1265 \mathrm{~s}, 1198 \mathrm{~m}, 1158 \mathrm{~m}$ sh., $1150 \mathrm{~m}, 1136 \mathrm{~m}, 1046$ w, $1018 \mathrm{~s}, 942 \mathrm{~m}, 922 \mathrm{~s}, 851 \mathrm{~m}, 828 \mathrm{~m}, 787 \mathrm{~m}, 724 \mathrm{w}, 690 \mathrm{~m}$, $656 \mathrm{~s}, 646 \mathrm{~m}$ sh., $624 \mathrm{~s}, 612 \mathrm{~s}, 565 \mathrm{~m}, 531 \mathrm{vs}, 481 \mathrm{~s}, 447 \mathrm{~s}, 438$ s, $406 \mathrm{~s}$.

Complexes $3 \mathbf{a}, \mathbf{4 a}$ and $\mathbf{5 a}$ were synthesized according to a similar procedure, except that $\mathrm{EtOH}$ was used as the only solvent both for $\operatorname{Ln}(\mathrm{acac})_{3} \cdot 3 \mathrm{H}_{2} \mathrm{O}$ and for benchrotrenecarboxylic acid. The yield was $\approx 30 \%$ for $\mathbf{3 a}$ and $\mathbf{4 a}$ and $\approx 40 \%$ for $5 \mathrm{a}$. The single-phase state of the samples was confirmed by X-ray powder diffraction.

For 3a, anal. calc. for $\mathrm{C}_{20} \mathrm{H}_{23} \mathrm{CrTbO}_{11}: \mathrm{C}, 36.94 ; \mathrm{H}, 3.57$. Found: $\mathrm{C}, 36.97 ; \mathrm{H}, 3.52 \%$.

ATR-IR of 3a, cm ${ }^{-1}$ : 3495 br. w, 3074 w, 1964 m, $1896 \mathrm{~s}$, 1865 vs, $1644 \mathrm{w}, 1578 \mathrm{~m}, 1546 \mathrm{~s}, 1512 \mathrm{~s}, 1454 \mathrm{~m}, 1436 \mathrm{~m}$, 1406 s, 1371 vs, 1266 s, 1197 m, 1161 m sh., 1150 m, 1134 m, 1049 w, 1018 s, 943 m, 922 s, 851 m, 829 m, 782 m, 724 w, $690 \mathrm{~m}, 656 \mathrm{~s}, 645 \mathrm{~m}$ sh., $624 \mathrm{vs}, 612 \mathrm{~s}, 566 \mathrm{~m}, 531 \mathrm{vs}, 481 \mathrm{~s}$, $446 \mathrm{~s}, 435 \mathrm{~s}, 411 \mathrm{~s}$.

For $4 a$, anal. calc. for $\mathrm{C}_{20} \mathrm{H}_{23} \mathrm{CrDyO}_{11}$ : C, 36.74; $\mathrm{H}, 3.55$. Found: $\mathrm{C}, 36.78 ; \mathrm{H}, 3.50 \%$.

ATR-IR of 4a, cm ${ }^{-1}$ : 3496 br. w, 3066 w, 1963 s, 1897 s, 1867 vs, $1650 \mathrm{w}, 1580 \mathrm{~m}, 1549 \mathrm{~s}, 1514 \mathrm{~s}, 1457 \mathrm{~m}, 1440 \mathrm{~m}$, 1408 s, 1374 vs, 1265 s, 1191 w, 1163 m sh., 1153 m, 1136 m, 1049 w, 1018 s, 943 w, 923 m, 851 m, 828 w, 780 m, 724 w, $690 \mathrm{~m}, 658 \mathrm{~s}, 647 \mathrm{~m}$ sh., $625 \mathrm{vs}, 613 \mathrm{~s}, 566 \mathrm{~m}, 531 \mathrm{~s}, 484 \mathrm{~s}, 449$ $m, 433 \mathrm{~m}, 405 \mathrm{~s}$.

For 5a, anal. calc. for $\mathrm{C}_{20} \mathrm{H}_{23} \mathrm{CrHoO}_{11}$ : C, 36.60; $\mathrm{H}, 3.53$. Found: $\mathrm{C}, 36.66 ; \mathrm{H}, 3.48 \%$.

ATR-IR of 5a, cm ${ }^{-1}$ : 3496 br. w, 3066 w, 1967 s, $1900 \mathrm{~s}$, 1875 vs, $1650 \mathrm{w}, 1580 \mathrm{~m}, 1549 \mathrm{~s}, 1514 \mathrm{~s}, 1457 \mathrm{~m}, 1440 \mathrm{~m}$, 1408 s, 1374 vs, 1265 s, 1191 w, 1163 m sh., 1153 m, 1136 m, 1049 w, 1018 s, 943 w, 923 m, 851 m, 828 w, 780 m, 724 w, $690 \mathrm{~m}, 658 \mathrm{~s}, 647 \mathrm{~m}$ sh., $625 \mathrm{vs}, 613 \mathrm{~s}, 566 \mathrm{~m}, 531 \mathrm{~s}, 484 \mathrm{~s}, 449$ m, $433 \mathrm{~m}, 405 \mathrm{~s}$.

\section{Synthesis of $\left[\operatorname{Ln}(\mathrm{BcrCOO})(\mathrm{acac})_{2}\left(\mathrm{H}_{2} \mathrm{O}\right)\right]_{\mathrm{n}}(\mathrm{R}=\mathrm{Tb}(3 \mathrm{~b})$, Dy (4b), Ho} (5b), $\operatorname{Er}(6), \operatorname{Tm}(7), \mathrm{Yb}(8), \mathrm{Y}(9))$

Complexes $\mathbf{3 b}, \mathbf{4 b}, \mathbf{5 b}$ and $\mathbf{6 - 9}$ were synthesized according to the procedure similar to that used in the case of complexes 1 and 2. Complexes 6-9 were also obtained using $\mathrm{EtOH}$ as the only solvent. In all of the syntheses, crystalline samples of complexes were obtained. The yields (based on $\mathrm{BcrCOOH}$ ) were $50-60 \%$. The single-phase state of the samples was confirmed by X-ray powder diffraction.

For 3b, anal. calc. for $\mathrm{C}_{20} \mathrm{H}_{21} \mathrm{CrTbO}_{10}: \mathrm{C}, 37.99 ; \mathrm{H}, 3.35$. Found: $\mathrm{C}, 38.05 ; \mathrm{H}, 3.30 \%$.

ATR-IR of 3b, cm ${ }^{-1}$ : 3489 br. w, 3085 w, 1964 m, 1891 vs, 1660 w, 1569 vs, 1517 vs, 1454 m, 1431 m, 1399 s, 1358 vs,
1266 s, 1198 w, 1150 w, 1048 w, 1015 s, 942 w, 925 m, 845 w, 824 w, 785 m, 719 w, 674 m, 653 s, 646 m sh., 613 s, 558 m, $528 \mathrm{~s}, 475 \mathrm{~s}, 443 \mathrm{~m}, 429 \mathrm{~m}$ sh., $414 \mathrm{~s}$.

For 4 b, anal. calc. for $\mathrm{C}_{20} \mathrm{H}_{21} \mathrm{CrDyO}_{10}$ : C, 37.78; $\mathrm{H}, 3.33$. Found: $\mathrm{C}, 37.82 ; \mathrm{H}, 3.30 \%$.

ATR-IR of 4b, $\mathrm{cm}^{-1}$ : 3490 br. w, $3084 \mathrm{w}, 1960 \mathrm{~m}, 1891 \mathrm{vs,}$ $1660 \mathrm{w}, 1569$ vs, 1518 vs, 1453 m, 1432 m, 1399 s, 1358 vs, 1266 s, 1198 w, 1149 w, 1048 w, 1015 s, 942 w, 925 m, 845 w, 826 w, 786 m, 719 w, 674 m, 653 s, 645 m sh., 614 s, 558 m, $528 \mathrm{~s}, 475 \mathrm{~s}, 443 \mathrm{~m}, 430 \mathrm{~m}$ sh., $414 \mathrm{~s}$.

For 5b, anal. calc. for $\mathrm{C}_{20} \mathrm{H}_{21} \mathrm{CrHoO}_{10}$ : C, 37.64; $\mathrm{H}, 3.32$. Found: $\mathrm{C}, 37.67 ; \mathrm{H}, 3.27 \%$.

ATR-IR of 5b, cm ${ }^{-1}: 3488$ br. w, 3083 w, 1958 m, 1892 vs, $1667 \mathrm{w}, 1568$ vs, 1515 vs, $1453 \mathrm{~m}, 1430 \mathrm{~m}, 1396 \mathrm{~s}, 1352$ vs, $1265 \mathrm{~s}, 1198 \mathrm{~m}, 1148 \mathrm{~m}, 1048 \mathrm{~m}, 1014 \mathrm{~s}, 942 \mathrm{~m}, 923 \mathrm{~s}, 845 \mathrm{~m}$, $828 \mathrm{w}, 786 \mathrm{~m}, 720 \mathrm{w}, 673 \mathrm{~m}, 651 \mathrm{~s}, 646 \mathrm{~m}$ sh., $613 \mathrm{~s}, 559 \mathrm{~s}$, 525 s, 467 s, 443 m, 423 m sh., 414 s.

For 6, anal. calc. for $\mathrm{C}_{20} \mathrm{H}_{21} \mathrm{CrErO}_{10}: \mathrm{C}, 37.50 ; \mathrm{H}, 3.30$. Found: C, $37.54 ; \mathrm{H}, 3.27 \%$.

ATR-IR of 6, cm ${ }^{-1}: 3491$ br. w, 3083 w, 1958 m, 1891 vs, 1668 w, 1569 vs, 1517 vs, 1453 m, 1432 m, 1399 s, 1352 vs, $1265 \mathrm{~s}, 1198 \mathrm{~m}, 1149 \mathrm{~m}, 1048 \mathrm{~m}, 1014 \mathrm{~s}, 941 \mathrm{~m}, 923 \mathrm{~s}, 846 \mathrm{~m}$, $827 \mathrm{w}, 786 \mathrm{~m}, 722 \mathrm{w}, 673 \mathrm{~m}, 651 \mathrm{~s}, 645 \mathrm{~m}$ sh., $613 \mathrm{~s}, 561 \mathrm{~s}, 525$ $\mathrm{s}, 466 \mathrm{~s}, 443 \mathrm{~m}, 426 \mathrm{~m}$ sh., $414 \mathrm{~s}$.

For 7, anal. calc. for $\mathrm{C}_{20} \mathrm{H}_{21} \mathrm{CrTmO}_{10}: \mathrm{C}, 37.40 ; \mathrm{H}, 3.30$. Found: $\mathrm{C}, 37.44 ; \mathrm{H}, 3.25 \%$.

ATR-IR of 7, cm ${ }^{-1}$ : 3491 br. w, 3082 w, 1957 m, 1892 vs, $1665 \mathrm{w}, 1569$ vs, 1517 vs, $1453 \mathrm{~m}, 1430 \mathrm{~m}, 1399 \mathrm{~s}, 1354$ vs, $1266 \mathrm{~s}, 1198 \mathrm{~m}, 1148 \mathrm{~m}, 1048 \mathrm{~m}, 1014 \mathrm{~s}, 943 \mathrm{~m}, 925 \mathrm{~s}, 845 \mathrm{~m}$, $828 \mathrm{w}, 786 \mathrm{~m}, 720 \mathrm{w}, 673 \mathrm{~m}, 651 \mathrm{~s}, 646 \mathrm{~m}$ sh., $613 \mathrm{vs}, 561 \mathrm{~s}$, $524 \mathrm{~s}, 466 \mathrm{~s}, 443 \mathrm{~m}, 428 \mathrm{~m}$ sh., $414 \mathrm{~s}$.

For 8, anal. calc. for $\mathrm{C}_{20} \mathrm{H}_{21} \mathrm{CrYbO}_{10}: \mathrm{C}, 37.16 ; \mathrm{H}, 3.27$. Found: $\mathrm{C}, 37.20 ; \mathrm{H}, 3.24 \%$.

ATR-IR of 8, cm ${ }^{-1}: 3485$ br. w, 3083 w, 1956 m, 1890 vs, 1657 w, 1572 vs, 1518 vs, 1453 m, 1430 m, 1399 s, 1354 vs, $1267 \mathrm{~s}, 1198 \mathrm{~m}, 1148 \mathrm{~m}, 1056 \mathrm{~m}, 1014 \mathrm{~s}, 943 \mathrm{~m}, 925 \mathrm{~s}, 845 \mathrm{~m}$, 827 w, 786 m, 722 w, 673 m, 651 s, 645 m sh., 613 vs, 561 s, $524 \mathrm{~s}, 466 \mathrm{~s}, 442 \mathrm{~m}, 428 \mathrm{~m}$ sh., $412 \mathrm{~s}$.

For 9, anal. calc. for $\mathrm{C}_{20} \mathrm{H}_{21} \mathrm{CrYO}_{10}: \mathrm{C}, 42.72 ; \mathrm{H}, 3.76$. Found: C, $42.77 ; \mathrm{H}, 3.73 \%$.

ATR-IR of 9, $\mathrm{cm}^{-1}$ : 3488 br. w, 3090 w, 1957 m, 1892 vs, $1670 \mathrm{w}, 1572$ vs, 1517 vs, 1453 m, 1430 m, 1399 s, 1354 vs, 1265 s, 1198 m, 1149 m, 1048 m, 1014 s, 942 m, 923 s, 845 m, 828 w, 786 m, 721 w, 674 m, 651 s, 646 m sh., 613 vs, 561 s, $525 \mathrm{~s}, 467 \mathrm{~s}, 443 \mathrm{~m}, 426 \mathrm{~m}$ sh., $414 \mathrm{~s}$.

\section{X-ray diffraction study}

Experimental data were collected on a Bruker SMART APEX2 instrument ${ }^{17}$ (Table S1). Absorption was taken into account by a semiempirical method based on equivalents using SADABS $\left(\mathbf{1}, \mathbf{3 a}, \mathbf{4 a}, \mathbf{4 b}, \mathbf{5 b}, \mathbf{8}, \mathbf{E u} \_\mathbf{1 D}\right)^{18}$ and TWINABS software $(\mathbf{2}) .{ }^{19}$ The structures were determined using a combination of the direct method and Fourier syntheses. The positions of $\mathrm{C}-\mathrm{H}$ hydrogen atoms were calculated from geometrical considerations, while the hydrogen atoms of water molecules were located in difference Fourier maps. The structures were refined by the 
full-matrix anisotropic least squares method. All the calculations were carried out using SHELXS-2014 and SHELXL2014 software. $^{20}$

The (1 $00 / 0$-1 $0 / 0$ ll 1 -1) matrix translates reduced cell of the structure of $4 a$ into the cell $(a=6.470, b=13.567, c=$ 14.977 $\AA, \alpha=117.01, \beta=98.91, \gamma=91.99^{\circ}$ ), which is close to the reduced cells of $\mathbf{1}, \mathbf{2}, \mathbf{3} \mathbf{a}$ and $\mathbf{5 a}$.

X-Ray powder diffraction analysis was carried out on a Bruker D8 ADVANCE X-Ray diffractometer $\left(\mathrm{CuK}_{\alpha}, \mathrm{Ni}\right.$-filter, LYNXEYE detector, reflection geometry). Single crystals suitable for X-ray diffraction were taken directly from the reaction mixture. Single-phase state of all of the samples was confirmed by powder XRD. In case of absence of suitable crystals, single-phase state of the product was proved by fullprofile Rietveld refinement (compounds 3b, 5a, 6, 7 and 9) (Table S2, Fig. S1).

\section{Results and discussion}

Synthesis of $\left[\operatorname{Ln}(\mathrm{BcrCOO})(\mathrm{acac})_{2}\left(\mathrm{H}_{2} \mathrm{O}\right)_{2}\right](\operatorname{Ln}=\mathrm{Eu}(1), \mathrm{Gd}(2), \mathrm{Tb}(3 \mathrm{a})$, Dy (4a), Ho (5a)) and $\left[\operatorname{Ln}(B c r C O O)(a c a c)_{2}\left(H_{2} \mathrm{O}\right)\right]_{n}(\operatorname{Ln}=\mathrm{Tb}(3 b)$, Dy (4b), $\mathrm{Ho}(5 \mathrm{~b}), \operatorname{Er}(6), \mathrm{Tm}(7), \mathrm{Yb}(8)$ and $\mathrm{Y}(9))$

In this work, two series of new isostructural heteroleptic complexes, the mononuclear $\left[\operatorname{Ln}(\mathrm{BcrCOO})(\mathrm{acac})_{2}\left(\mathrm{H}_{2} \mathrm{O}\right)_{2}\right](\mathrm{Ln}=$ $\mathrm{Eu}-\mathrm{Ho})$ one and the 1D-polymeric $\left[\mathrm{Ln}(\mathrm{BcrCOO})(\mathrm{acac})_{2}\left(\mathrm{H}_{2} \mathrm{O}\right)\right]_{n}$ $(\mathrm{Ln}=\mathrm{Dy}-\mathrm{Yb}$ and $\mathrm{Y}$ ) one, were synthesized by the reaction of lanthanides acetylacetonates with $\mathrm{BcrCOOH}$ in solvosystems of various compositions. The effect of the nature of $\mathrm{Ln}$ ions and, less, of the solvosystem composition on the structure of the reaction products was shown in the $\mathrm{Eu}-\mathrm{Gd}-\mathrm{Tb}-\mathrm{Dy}-\mathrm{Ho}-$ $\mathrm{Er}-\mathrm{Tm}-\mathrm{Yb}-\mathrm{Y}$ series. The synthetic methodology is presented in Scheme 1.

The reactions carried out in the $\mathrm{PrOH} / \mathrm{THF} / \mathrm{H}_{2} \mathrm{O}$ mixture afford one-phase samples of mononuclear complexes $\left[\operatorname{Ln}(\mathrm{BcrCOO})(\mathrm{acac})_{2}\left(\mathrm{H}_{2} \mathrm{O}\right)_{2}\right] \quad(\mathrm{Ln}=\mathrm{Eu}(1), \mathrm{Gd}(2))$ and 1Dpolymeric complexes $\left[\operatorname{Ln}(\mathrm{BcrCOO})(\mathrm{acac})_{2}\left(\mathrm{H}_{2} \mathrm{O}\right)_{2}\right]_{n}(\mathrm{Ln}=\mathrm{Tb}(\mathbf{3 b})$, $\operatorname{Dy}(4 b), H o(5 b), \operatorname{Er}(6), \operatorname{Tm}(7), \mathrm{Yb}(8)$ and $Y(9))$. The reactions carried out in EtOH were found to afford one-phase mononuclear complexes also for Tb (3a), Dy (4a) and Ho (5a), whereas 1D-polymeric complexes were only obtained for the heaviest members of the series, i.e., $\operatorname{Er}(6), \operatorname{Tm}(7), \mathrm{Yb}(\mathbf{8})$, as well as $Y(9)$.

Since the compositions of the formula units of mononuclear and 1D-polymeric complexes differ insignificantly (by one water molecule). Formation of both mononuclear and 1D-polymeric complexes is possible in all the solvosystems under investigation. Therefore, it can be assumed that the observed differences are due to different solubility of complexes in the "mononuclear complex/1D-polymeric complex" pair in the same solvosystem for different Ln atoms. In case of the first two members of the investigated series, namely Eu and $\mathrm{Gd}$, mononuclear complexes $\mathbf{1}$ and $\mathbf{2}$ with the composition $\left[\mathrm{Ln}(\mathrm{acac})_{2}(\mathrm{BcrCOO})\left(\mathrm{H}_{2} \mathrm{O}\right)_{2}\right.$ ] apparently have much lower solubility in the solvosystems under study, since these complexes crystallize irrespectively of the solvosystem composition. In fact, complexes $\mathbf{1}$ and $\mathbf{2}$ were isolated in rather high yields from the $\mathrm{i} \mathrm{PrOH} / \mathrm{THF} / \mathrm{H}_{2} \mathrm{O}$ solvosystem with a volume ratio of the components of $11: 11: 3$, respectively. However, the yields of $\mathbf{1}$ and $\mathbf{2}$ become much lower in nonabsolute EtOH. This is apparently due to the relatively small excess of water in the system, combined with the extremely high solubility of the target reaction products in EtOH.

In contrast, 1D-polymeric complexes, $\left[\operatorname{Ln}(\mathrm{acac})_{2}(\mathrm{BcrCOO})\left(\mathrm{H}_{2} \mathrm{O}\right)\right]_{n}$, have the lowest solubility in case of $\mathrm{Er}-\mathrm{Yb}$ and $\mathrm{Y}$. In fact, complexes 6-9 were obtained irrespective of the solvosystem composition and the yields of the complexes are relatively high in all cases.

As noted above, formation of both mononuclear complexes 3a-5a $\left[\mathrm{Ln}(\mathrm{acac})_{2}(\mathrm{BcrCOO})\left(\mathrm{H}_{2} \mathrm{O}\right)_{2}\right]$ (crystallization from EtOH) and 1D-polymeric complexes $\mathbf{3 b}$-5b $\left[\mathrm{Ln}(\mathrm{acac})_{2}(\mathrm{BcrCOO})\left(\mathrm{H}_{2} \mathrm{O}\right)\right]_{n}$ (crystallization from ${ }^{\mathrm{i}} \mathrm{PrOH} / \mathrm{THF} / \mathrm{H}_{2} \mathrm{O}$ mixture) is possible in case of Tb, Dy and Ho.

Thus, it can be stated that as the atomic number of Ln increases in the series $\mathrm{Eu}-\mathrm{Yb}$, the solubility of mononuclear complexes $\left[\mathrm{Ln}(\mathrm{acac})_{2}(\mathrm{BcrCOO})\left(\mathrm{H}_{2} \mathrm{O}\right)_{2}\right.$ ] increases, whereas the solubility of 1D-polymeric complexes $\left[\mathrm{Ln}(\mathrm{acac})_{2}(\mathrm{BcrCOO})\left(\mathrm{H}_{2} \mathrm{O}\right)\right]_{n}$ decreases. The solubility of $\mathrm{Y}$ complexes is similar to that of the complexes of heavy lanthanides. In the Ln series under investigation, Tb, Dy and Ho are "transition" elements that can form both mononuclear and 1D-polymeric complexes. In this case, the structure of the resulting complexes can be controlled by varying the composition of the solvosystem (more exactly, the amount of water in it).

\section{Structures of the complexes}

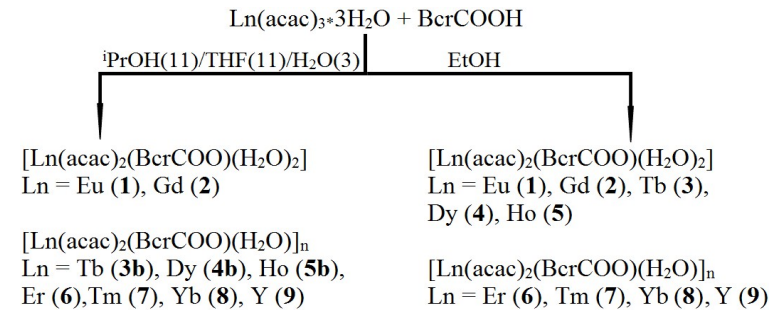

Scheme 1. Synthetic methodology used in this study. 


\section{(1)}

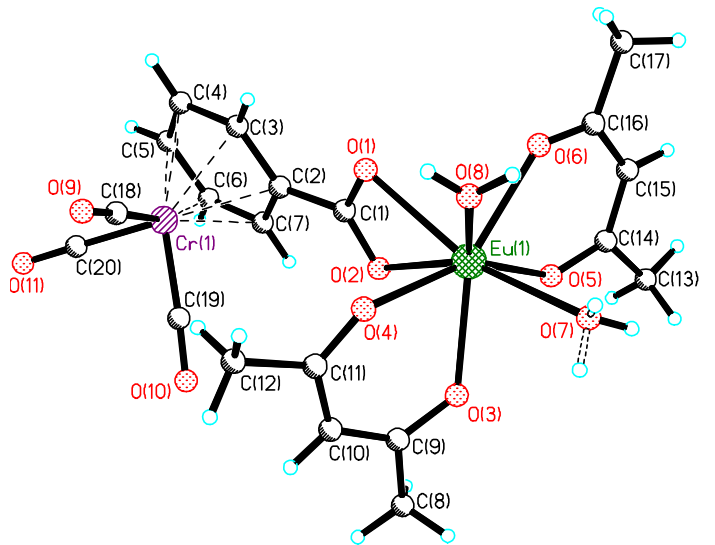

a

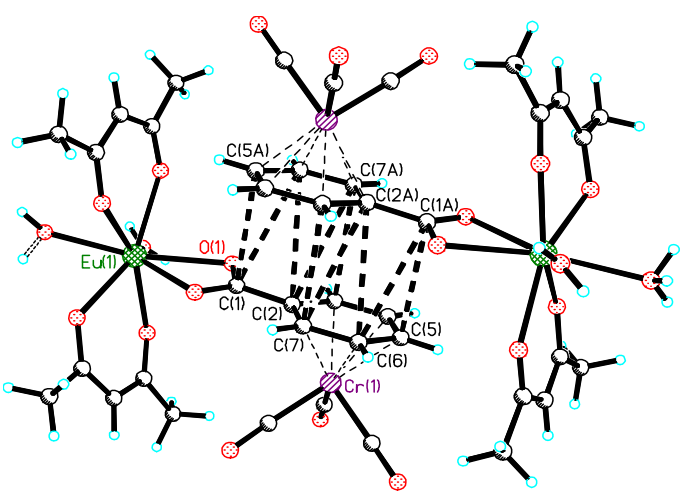

b

Fig. 1 Structure of the complex in compound 1 (a); centrosymmetric dimers in compound $\mathbf{1}$, with distances shorter than $3.5 \AA ̊$ indicated (b).

The structure of the mononuclear complex in compound 1 (compounds $\mathbf{1}, \mathbf{2}, \mathbf{3 a}, \mathbf{4 a}$, and $\mathbf{5 a}$ are isostructural) is shown in Fig. 1a. The coordination number (CN) of the Eu atom equals 8; the polyhedron is most similar to a two-capped trigonal prism with the basis formed by the $O(1,2,4)$ and $O(5,6,7)$ atoms. Naturally, the $\eta^{2}$-carboxy group of the $\mathrm{BcrCOO}^{-}$is rigid and therefore causes a strong distortion of the polyhedron. The potential donors of $\mathrm{H}$ atoms in hydrogen bonds are located at distances of $2.75 \AA$, $3.04 \AA$, and $3.05 \AA$ from the O(7) atom of the $\mathrm{H}_{2} \mathrm{O}$ molecule. Difference syntheses in the vicinity of the $\mathrm{O}(7)$ atom localized three positions of $\mathrm{H}$ atoms; halfpopulations were assigned to two of them. The coordinates of all the three $\mathrm{H}$ atoms in compound $\mathbf{3 a}$ that is isostructural with 1 , were refined; the $U_{\text {iso }}$ of the $H$ atoms were assumed to be $20 \%$ larger than the $U_{\text {eq }}$ of $\mathrm{O}(7)$. The $\mathrm{O}-\mathrm{H}$...O hydrogen bonds (Table S3) in structure 1 link the complexes into bands (Fig. S2). The stacking interactions between the Ph moieties of the BcrCOO ligands in structure 1 (Fig. 1b) link bands into layers. A layer contains $\mathrm{C}(4)-\mathrm{H}$...O hydrogen bonds (Table S3). There is one contact $\mathrm{C}(15)-\mathrm{H} \ldots \mathrm{O}$ (C-H $0.95 \AA \AA$, H...O $2.74 \AA$, C...H

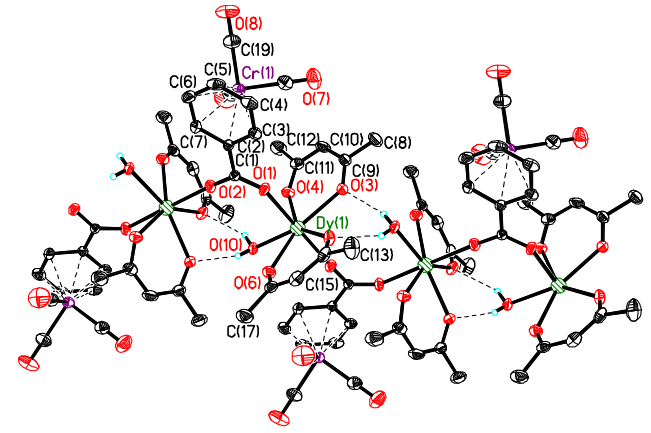

a

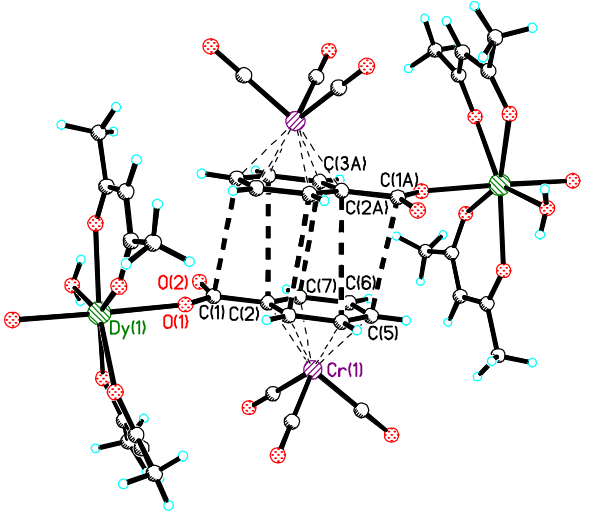

b

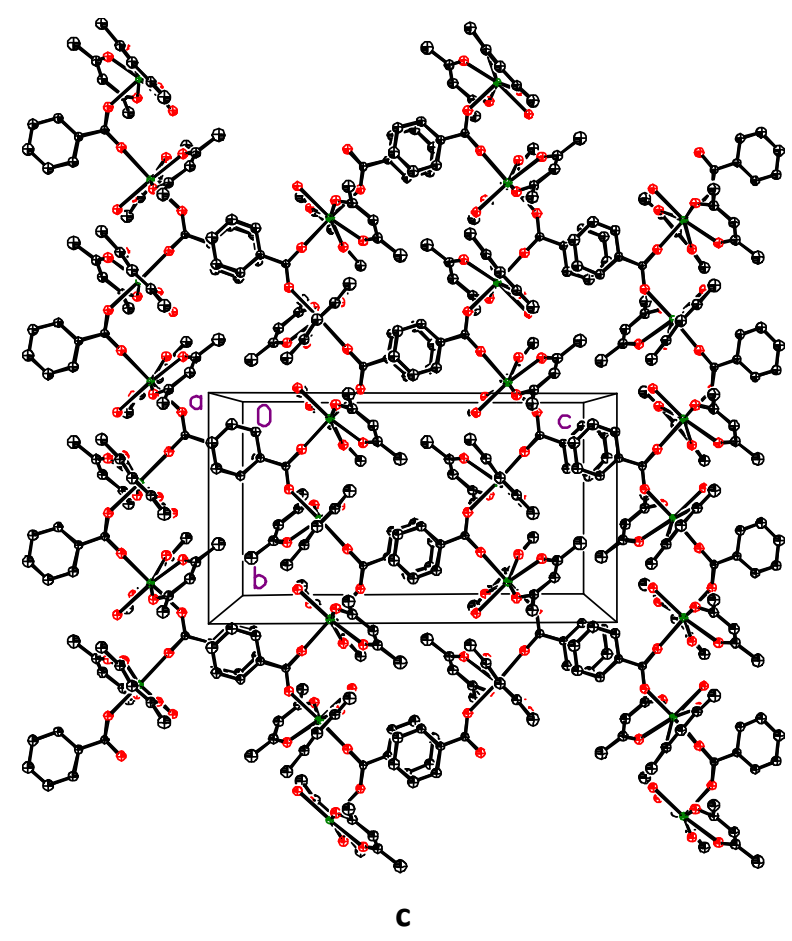

Fig. 2 Structure of the polymeric chain in compound $\mathbf{4 b}$ (a); stacking interactions between the $\mathrm{Ph}$ moieties, with distances shorter than $3.5 \AA$ indicated (b); projection of the structure along $a$ axis $\left(\mathrm{Cr}(\mathrm{CO})_{3}\right.$ moieties are omitted for clarity) (c). 


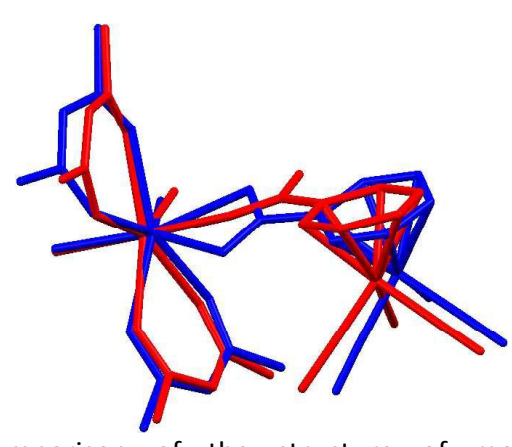

Fig. 3 Comparison of the structure of mononuclear complex 4a (blue) and a monomeric unit in structure of 1Dpolymeric $\mathbf{4 b}$ (red).

3.569(4) $\AA$, $\mathrm{C}-\mathrm{H} . . . \mathrm{O} 146^{\circ}$ ) between the layers that may, under certain assumptions, be attributed to hydrogen bonds.

Structure $4 b$ (compounds $3 b, 4 b, 5 b$, and $6-9$ are isostructural ${ }^{*}$ ) is formed by polymeric chains (Fig. 2a) parallel to $b$ axis. The coordination number $(\mathrm{CN})$ of the Dy atom is 7 ; the polyhedron is a pentagonal bipyramid with its basis formed by $\mathrm{O}$ atoms from acac and $\mathrm{H}_{2} \mathrm{O}$. The $\mathrm{O}$ atoms of the bridging $\mathrm{BcrCOO}^{-}$ligand occupy the apical positions. The O-H...O hydrogen bonds (Table S4) link the chain additionally. The stacking interactions between $\mathrm{Ph}$ moieties of the BcrCOO ligands linked by a center of inversion are similar to those in 1 (Fig. 1b), and combine the chains into layers (Fig. 2b). Previously, we have found a chain with a similar structure in the $\left[\mathrm{Ln}(\mathrm{CymCOO})(\mathrm{acac})_{2}\left(\mathrm{H}_{2} \mathrm{O}\right)\right]_{n}(\mathrm{Ln}=\mathrm{Eu}-\mathrm{Er}){ }^{13 \mathrm{e}}$

The overall arrangement of ligands around the $\mathrm{Ln}$ atom in structures $\mathbf{1}$ and $\mathbf{4 b}$ is similar (Fig. 3). Minimization of squared distances between the Dy atoms, five $O$ atoms of the base of the pentagonal bipyramid (4b) and $\mathrm{Eu}(1), \mathrm{O}(3-6,8)$ atoms (1) results in RMS $=0.25 \AA$. .

As it was noted above, the coordination modes of BcrCOO in the mononuclear and 1D-polymeric complexes are different: only chelate groups are present in the structures of mononuclear complexes $\mathbf{1}, \mathbf{2}, \mathbf{3 a}, \mathbf{4 a}, \mathbf{5 a}$, whereas only bridging groups are present in 1D-polymers $\mathbf{3 b}, \mathbf{4 b}, \mathbf{5 b}, \mathbf{6 - 9}$. It is known ${ }^{21}$ that the bands corresponding to the stretching vibrations of the $\mathrm{COO}^{-}$groups in the IR spectra of carboxylate complexes are very sensitive to the coordination mode of these groups. This is evidenced by the frequency difference $\Delta=$ $v_{\text {as }}(\mathrm{COO})-v_{\text {sym }}(\mathrm{COO})$ : the $\Delta$ value in complexes with chelate coordination of the carboxy groups is noticeably smaller than in carboxylates with bridging groups. Therefore, IR spectroscopy is a convenient method to confirm the type of coordination of carboxy groups.

The ATR-IR spectra of mononuclear and 1D-polymeric dysprosium-containing complexes $\mathbf{4 a}$ and $\mathbf{4 b}$ in the range of wave numbers $1320-1600 \mathrm{~cm}^{-1}$ were compared (Fig. 4a).

It can be seen that the $\Delta$ value for complex $4 a\left(141 \mathrm{~cm}^{-1}\right)$ is considerably smaller than that for $\mathbf{4 b}\left(165 \mathrm{~cm}^{-1}\right)$, which totally

\footnotetext{
* In one of the syntheses with Eu, we collected a single crystal isostructural to compounds $\mathbf{4 b}, \mathbf{5 b}, \mathbf{6 - 9}$. However, the $X$-ray diffraction pattern of the reaction product did not show any traces of polymeric Eu_1D. Taking into account the differences in the X-ray diffraction patterns of compounds 1 and Eu_1D (Fig.S3) and the accumulation time it the range of $2 \vartheta 6-14^{\circ}$, it can be stated that the admixture content is less than $0.3 \%$
}

6 | J. Name., 2012, 00, 1-3 agrees with literature data and indicates the difference between the $\mathrm{BcrCOO}^{-}$coordination in the structure of complexes.

Furthermore, comparison of IR spectra of mononuclear and 1D-polymeric complexes shows that the number of bands corresponding to the stretching vibrations of carbonyl groups in the $\mathrm{Bcr}$ moieties $\left(\mathrm{Bcr}=\left(\eta^{6}-\mathrm{C}_{6} \mathrm{H}_{5}\right) \mathrm{Cr}(\mathrm{CO})_{3}\right)$ differs between these complexes. Three distinct bands (1867, 1897 and 1963 $\mathrm{cm}^{-1}$ for 4 a) are observed in the region of $1800-2000 \mathrm{~cm}^{-1}$ in the spectra of mononuclear complexes 1, 2, 3a, 4a, 5a. Only two bands (1891 and $1960 \mathrm{~cm}^{-1}$ for $\mathbf{4 b}$ ) are discernible in the spectra of $1 \mathrm{D}$-polymeric complexes $\mathbf{3 b} \mathbf{6} \mathbf{4} \mathbf{b}, \mathbf{5 b}, \mathbf{6 - 9}$, whereas the third band is almost not recorded, even as an indistinct shoulder (Fig. 4b). This difference persisted in numerous recordings of the spectra of all samples of the complexes (preliminarily, it was confirmed by XRD that they were onephase and individual), which allows us to conclude its significance. However, we failed to explain this phenomenon from the standpoint of various structural features of the $\mathrm{CO}$ group positions in mononuclear and polymeric complexes. Nevertheless, the absolute reproducibility of this difference makes it possible to use a comparison of IR spectra in the specified region (together with the analysis of the positions of
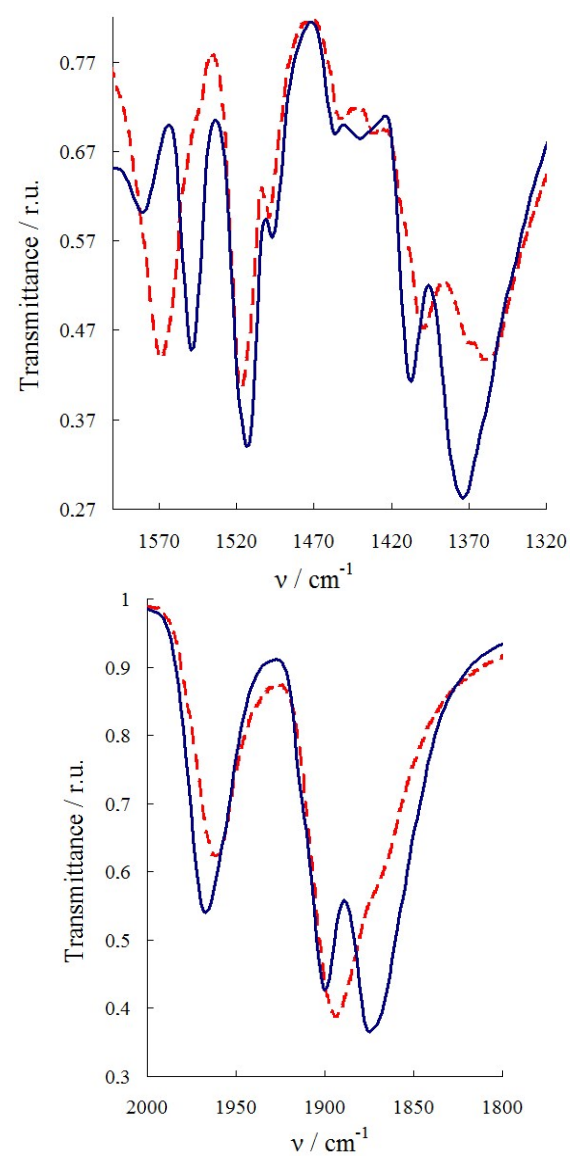

Fig. 4 ATR-IR spectra of complexes $\mathbf{4 a}(-)$ and $\mathbf{4 b}(---)$ in the range of $1320-1600 \mathrm{~cm}^{-1}$ (top) and $1800-2000 \mathrm{~cm}^{-1}$ (bottom). 
bands corresponding to the stretching vibrations of $\mathrm{COO}^{-}$ groups) as a reliable method for preliminary identification of the main structural motif (mononuclear or 1D-polymeric) in heteroleptic benchrotrenecarboxylate complexes of lanthanides formed in $\mathrm{Ln}(\mathrm{acac})_{3} \cdot 3 \mathrm{H}_{2} \mathrm{O}-\mathrm{BcrCOOH}$ - Solv (where Solv is an individual organic solvent or a solvent mixture) systems.

\section{Magnetic behavior}

Primarily, it should be noted that the magnetic behavior of both the mononuclear and 1D-polymeric benchrotrenecarboxylates obtained is due only to the contribution of $\mathrm{Ln}^{3+}$ ions since the benchrotrene moieties are diamagnetic. The $\chi_{m} T$ vs. $T$ plots for mononuclear $\left[\mathrm{Ln}(\mathrm{BcrCOO})(\mathrm{acac})_{2}\left(\mathrm{H}_{2} \mathrm{O}\right)_{2}\right](\mathrm{Ln}=\mathrm{Eu}(\mathbf{1}), \mathrm{Gd}(\mathbf{2}), \mathrm{Tb}(\mathbf{3 a}), \mathrm{Dy}(\mathbf{4 a})$, $\mathrm{Ho}(5 \mathrm{a}))$ and 1D-polymeric $\left[\operatorname{Ln}(\mathrm{BcrCOO})(\mathrm{acac})_{2}\left(\mathrm{H}_{2} \mathrm{O}\right)\right]_{n}(\mathrm{Ln}=\mathrm{Tb}$ (3b), Dy (4b), Ho (5b), Er (6), Tm (7), (Yb (8)) complexes in dc field of 1000 Oe were investigated in the temperature range of $2-300 \mathrm{~K}$ (Fig. 5). The $\chi_{m} T$ values at $300 \mathrm{~K}$ are close to the theoretical ones for corresponding single $\mathrm{Ln}^{3+}$ ions (Table 1 ).

The magnetic behavior of complex 1 (Eu) is typical of the known mononuclear, polynuclear, and polymeric $\mathrm{Eu}^{3+}$ complexes. ${ }^{13 e, 23}$ Unlike the other $\mathrm{Ln}^{3+}$, the energy spectrum of the $\mathrm{Eu}^{3+}\left(4 f^{6}\right)$ is characterized by low splitting between the non-magnetic ground state ${ }^{7} F_{O}$ and the first excited multiplet. Taking the spin-orbital Hamiltonian $H_{\mathrm{SO}}=\lambda \mathrm{L} \cdot \mathrm{S}$ into account, the energy of the first excited state, ${ }^{7} F_{1}$, is only $\lambda \mathrm{cm}^{-1}$ higher than that of the ${ }^{7} F_{O}$ level. Up to $300 \mathrm{~K}$, the energy of thermal fluctuations is sufficient for population of only three first energy levels at $0, \lambda$, and $3 \lambda$. This results in appearance of a considerable magnetic moment at room temperature (see Fig. 5). As expected in the case where the $k_{B} T$ energy is of the same order as $\lambda$, the value $\chi_{m} T=1.52 \mathrm{~cm}^{3} \mathrm{~K} / \mathrm{mol}$ at $300 \mathrm{~K}$ for compound 1 does not reach the theoretical high-temperature limit of $12 N_{A} \mu_{B}^{2} / k_{B}=4.5 \mathrm{~cm}^{3} \mathrm{~K} / \mathrm{mol}^{24 a}$ In this case, a monotonous decrease in $\chi_{m} T$ with a temperature lowering to $0.04 \mathrm{~cm}^{3} \mathrm{~K} / \mathrm{mol}$ at $\mathrm{T}=2 \mathrm{~K}$ is observed. Like in the majority of other $\mathrm{Eu}^{3+}$ complexes, this lowering is due to a decrease in the population of excited $m_{j}$ levels. Based on the energy spectrum obtained from the spin-orbital Hamiltonian $H_{s o}$, the theoretical temperature dependence of magnetic susceptibility in the weak magnetic field approximation can be calculated using the Van-Vleck equation. ${ }^{24}$ Thus, just one parameter of spin-orbital interaction, $\lambda$, is sufficient for simulation of experimental data. In the case of complex 1, the best fit of the theoretical curve to experimental data is reached at $\lambda=265 \pm 3 \mathrm{~cm}^{-1}$ (or $385 \pm 4 \mathrm{~K}$ ). Using the Caro-Porcher equation, ${ }^{25}$ the value between the ${ }^{7} F_{O}$ and ${ }^{7} F_{1}$ levels, $\lambda_{C-P}=245 \mathrm{~cm}^{-1}$, was calculated for 1 . It can be seen that the $\lambda_{c-p}$ and $\lambda$ values are in satisfactory agreement. The $\lambda$ value is rather low. A similar value $\lambda=253(2) \mathrm{cm}^{-1}$ was obtained for the $\left\{\left[\mathrm{Eu}_{2}(\mathrm{dpa})_{2}\left(\mathrm{C}_{2} \mathrm{O}_{4}\right)_{2}\left(\mathrm{H}_{2} \mathrm{O}\right)_{2}\right] \cdot\left(\mathrm{H}_{2} \mathrm{O}\right)\right\}_{n}$ polymer $\left(\mathrm{dpa}=2,2^{\prime}-(2-\right.$-methylbenzimidazolium-1,3-diyl)diacetate, $\mathrm{C}_{2} \mathrm{O}_{4}{ }^{2-}=$ oxalate), ${ }^{26}$ which is apparently due to the crystal field effect in the structures under consideration.

It should be noted that determination of $\lambda$ value for $\mathbf{1}$ from the luminescence data is not possible, since the benchrotrene moiety manifests a luminescence quenching effect, similarly to cymantrene moiety. ${ }^{13 \mathrm{~b}}$ In such cases, the $\lambda$ value can only be determined from the DC magnetic susceptibility data.

The ground state of $\mathrm{Gd}^{3+}\left(4 f^{7}\right)$ is ${ }^{8} \mathrm{~S}_{7 / 2}$. Since orbital quantum number, $L$, equals to 0 , the spin-orbit coupling is absent. In addition, the first excited state lies about $30000 \mathrm{~cm}^{-1}$ above the ground state. Thus, the magnetic susceptibility of compounds containing $\mathrm{Gd}^{3+}$ is almost perfectly isotropic, and follows the Curie law ${ }^{24 a}$.

The $\chi_{m} T$ value of mononuclear $\mathrm{Gd}$ complex 2 remains virtually constant down to $25 \mathrm{~K}$ and decreases abruptly upon reaching $\approx 10 \mathrm{~K}$ (Fig. 5). Such behavior is apparently attributable to the weak intermolecular antiferromagnetic interactions between the $\mathrm{Gd}^{3+}$ ions. It is known that in the solid state the molecular magnetic centers, even if they are well separated from each other, are rarely perfectly isolated from a magnetic viewpoint ${ }^{24 a}$.

In order to estimate the value of the magnetic interactions in $\mathbf{2}$ the temperature dependence of $\chi^{\top}$ product of $\mathbf{2}$ was fitted using Phi program developed by Chilton et $\mathrm{al}^{27}$. The following

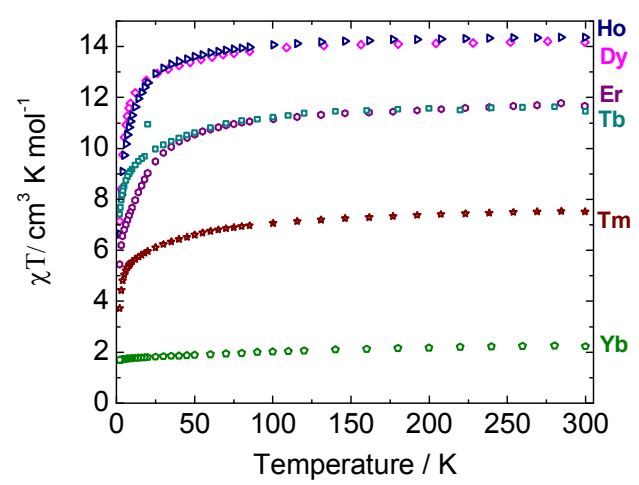

Fig. 5. Plots of $\chi_{m} T$ vs. temperature for mononuclear $\mathbf{1}(\mathrm{Eu}), \mathbf{2}(\mathrm{Gd}), \mathbf{3 a}(\mathrm{Tb}), \mathbf{4 a}(\mathrm{Dy}), \mathbf{5 a}(\mathrm{Ho})$ (left) and 1D-polymeric 3b (Tb), 4b (Dy), 5b (Ho), 6-8 (Er, Tm, Yb) (right) complexes in 1000 Oe dc field. The lines show the best fit of the theoretical model described in the text to the experimental data for Eu and Gd compounds ( $\mathbf{1}$ and $\mathbf{2}$ ). 
Table 1. DC-magnetic characteristics of complexes.

\begin{tabular}{|c|c|c|c|}
\hline $\operatorname{Ln}$ & $\begin{array}{c}\chi_{m} T(300 \mathrm{~K}) \\
\mathrm{cm}^{3} \mathrm{~mol}^{-1} \mathrm{~K}\end{array}$ & $\begin{array}{c}\chi_{m} T \text { (theor) } \\
\mathrm{cm}^{3} \mathrm{~mol}^{-1} \mathrm{~K} \\
{[22]}\end{array}$ & $\begin{array}{c}\chi_{m} T(2 \mathrm{~K}) \\
\mathrm{cm}^{3} \mathrm{~mol}^{-1} \mathrm{~K}\end{array}$ \\
\hline \multicolumn{4}{|c|}{ Mononuclear complexes } \\
\hline Eu (1) & 1.52 & - & 0.04 \\
\hline $\mathrm{Gd}(2)$ & 7.88 & 7.88 & 5.16 \\
\hline $\mathrm{Tb}(3 \mathrm{a})$ & 11.75 & 11.82 & 7.67 \\
\hline Dy (4a) & 14.42 & 14.17 & 6.82 \\
\hline Ho (5a) & 14.21 & 14.07 & 4.63 \\
\hline \multicolumn{4}{|c|}{ 1D-Polymeric complexes } \\
\hline $\mathrm{Tb}(\mathbf{3 b})$ & 11.46 & 11.82 & 7.42 \\
\hline Dy (4b) & 14.17 & 14.17 & 7.15 \\
\hline $\mathrm{Ho}(5 b)$ & 14.36 & 14.07 & 6.63 \\
\hline $\operatorname{Er}(6)$ & 11.67 & 11.48 & 5.45 \\
\hline $\operatorname{Tm}(7)$ & 7.52 & 7.15 & 3.72 \\
\hline $\mathrm{Yb}(8)$ & 2.23 & 2.57 & 1.69 \\
\hline
\end{tabular}

parameters were obtained: $g=2.00$, zero-field splitting parameter $D=0.314 \mathrm{~cm}^{-1}$ and intermolecular interaction $z J=-$ $0.004 \mathrm{~cm}^{-1}$.

The $\chi_{m} T$ values for Tb ( $3 a$ and $3 \mathbf{b}$ ), Dy (4a and $4 \mathbf{b}$ ), Ho (5a and $\mathbf{5 b}), \operatorname{Er}(\mathbf{6}), \operatorname{Tm}(\mathbf{7})$, and $\mathrm{Yb}(\mathbf{8})$ complexes decrease very slowly from room temperature to ca $100 \mathrm{~K}$, and more abruptly below this temperature to reach the minimum values at $\mathrm{T}=2 \mathrm{~K}$ (see Table 1 and Fig. 5). Such behavior is consistent with depopulation of the $m_{\mathrm{J}}$ sub-levels, with zero-field splitting effects, and/or occurrence of very weak antiferromagnetic interactions between the lanthanide ions. These low temperature effects are also observed on the field dependencies of the magnetization for $\mathrm{Tb}(\mathbf{3 a}, \mathbf{3 b})$, Dy (4a) and $\mathrm{Yb}$ (8) (Fig. S4, S5) which show no sign of saturation at magnetic fields up to $7 \mathrm{~T}$. Nonsuperposition of $M$ vs. H/T on a single master curve also suggests the presence of magnetic anisotropy.

We measured the $a c$ susceptibility of complexes containing anisotropic ions, namely, $\mathrm{Tb}^{3+}, \mathrm{Dy}^{3+}, \mathrm{Ho}^{3+}, \mathrm{Er}^{3+}, \mathrm{Tm}^{3+}$ and $\mathrm{Yb}^{3+}$, in order to find out whether the complexes have properties characteristic of molecular magnets. No non-zero out-of-phase component of the dynamic magnetic susceptibility $\chi$ " was found for Ho (both $5 \mathbf{a}, \mathbf{5 b}$ ), and $\operatorname{Tm}(\mathbf{7})$ complexes. For the complexes of Dy $(\mathbf{4 a}, \mathbf{4 b})$ and $\operatorname{Er}(\mathbf{6})$, non-zero $\chi^{\prime \prime}$ values are observed even in zero field. For the $\mathrm{Tb}(\mathbf{3 a}, \mathbf{3 b})$ and $\mathrm{Yb}(\mathbf{8})$ complexes $\chi^{\prime \prime}>0$ values are only observed in non-zero dc fields.

For complex 3a (Tb), at temperatures below $6 \mathrm{~K}$ in zero magnetic field, some growth of the out-of-phase component of dynamic magnetic susceptibility $\chi^{\prime \prime}$ is observed at low temperatures, which attests to presence of slow magnetic relaxation. Application of various magnetic fields allowed us to determine the optimal field, $\mathrm{H}_{\mathrm{DC}}=2000 \mathrm{Oe}$, where the quantum tunneling probability is the lowest (Fig. S6), and hence the relaxation time is the largest. The frequency dependences of $\chi^{\prime \prime}$ in the optimal magnetic field were studied
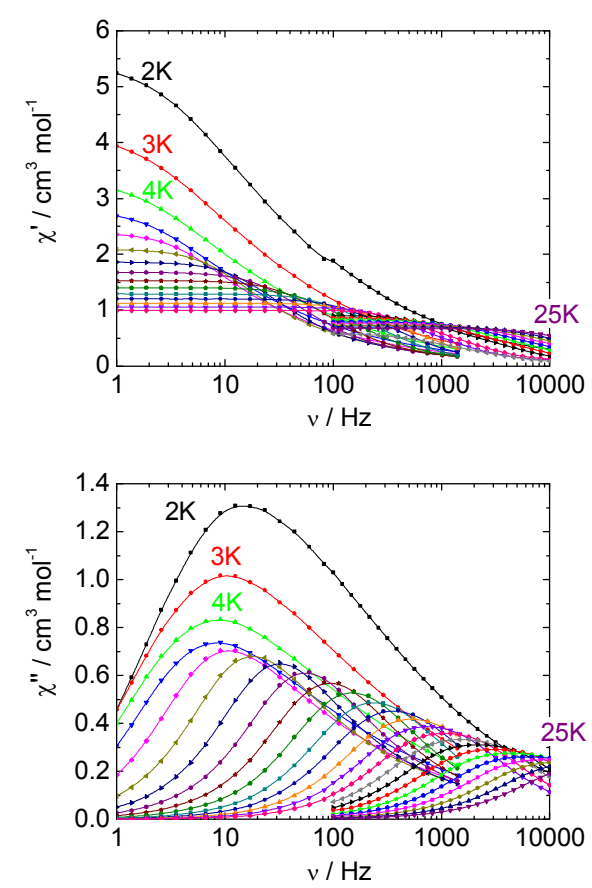

Fig. 6. Frequency dependence of the in-phase $\chi^{\prime}$ (top) and out-of-phase $\chi^{\prime \prime}$ (bottom) components of the ac susceptibility for complex 4a (Dy) in the zero dc field (2$25 \mathrm{~K}$, step $1 \mathrm{~K}$ ). Solid lines are visual guides.

in the temperature range of $2-7 \mathrm{~K}$ (Fig. S6). The temperature dependence of the relaxation time has been extracted from the frequency dependences of the ac susceptibility (Fig. S6) by fitting to the generalized Debye model (Table S5). Using the Arrhenius law $\tau=\tau_{0} \cdot \exp \left(\Delta_{\text {eff }} / k_{B} T\right)$, the pre-exponential factor $\left(\tau_{0}\right.$ $\left.=4 \cdot 10^{-6} \mathrm{~s}\right)$ and the energy barrier $\left(\Delta_{\text {eff }} / \mathrm{k}_{\mathrm{B}}=5 \mathrm{~K}\right)$ were determined (Fig. S7).

For complex 4a (Dy), non-zero $\chi$ " values are observed even in zero dc field (Fig. 6). We failed to fit the ac susceptibility data for 4a with single generalized Debye model. Therefore, the ac susceptibility data were fitted with the linear combination of two Debye models (Fig. S8). In such a way, the low frequency (LF) and the high frequency (HF) components of the signal were separated. The $\tau\left(\mathrm{T}^{-1}\right)$ plots for complex $4 \mathrm{a}$ are presented in Fig. 7. It can be seen from Fig. 6, 7 and Table S6 that at temperatures below $5 \mathrm{~K}$ the frequencies of the maxima on $\chi^{\prime \prime}(v)$ dependencies are shifted toward the high frequency range in both cases (LF and HF). The similar behavior was observed earlier ${ }^{28}$ and can be attributed to appearance of additional pathways for quantum relaxation and/or to very weak magnetic exchange interactions which result in shortrange magnetic ordering/glassy behavior that, in turn, affects the magnetic relaxation at $\mathrm{T}<5 \mathrm{~K}$. Approximation of the high temperature regions $(17-20 \mathrm{~K})$ of the $\tau\left(T^{-1}\right)$ plots by the Arrhenius equation allowed us to determine the potential barriers of magnetization reversal, $\Delta_{\text {eff }} / k_{\mathrm{B}}=100 \mathrm{~K}$ and $118 \mathrm{~K}$, and the pre-exponential factors, $\tau_{0}=5.6 \cdot 10^{-7} \mathrm{~s}$ and $4.5 \cdot 10^{-8} \mathrm{~s}$ for LF and HF, respectively. 

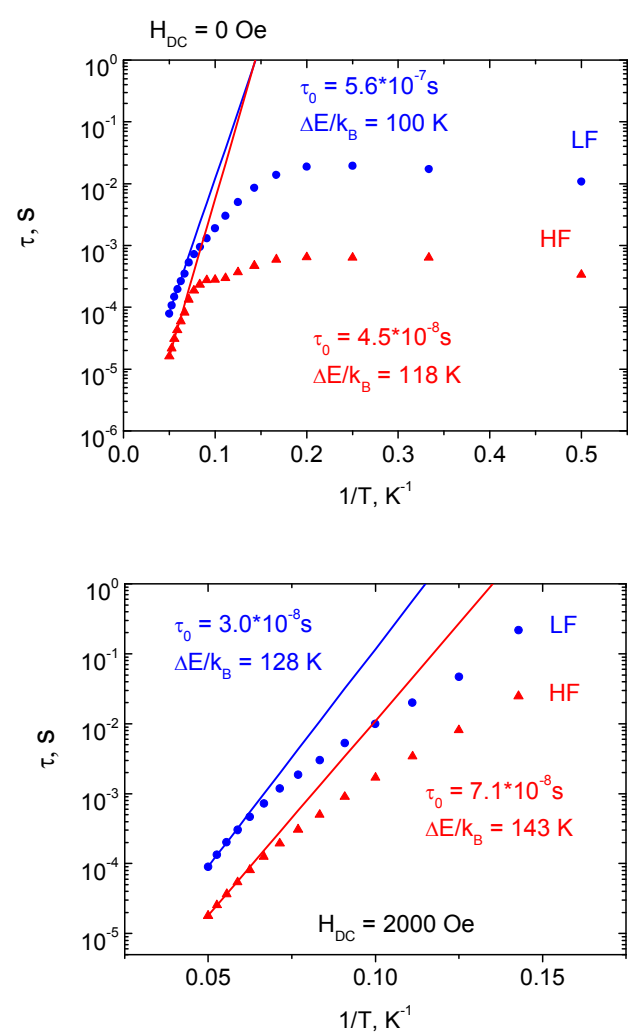

Fig. 7. Plot of relaxation time vs. inverse temperature for 4a (Dy) in zero (top) and 2000 Oe (bottom) dc field. Solid line is the best fit to the Arrhenius law.

The magnetization dynamics of $\mathbf{4 a}$ (Dy) have been also studied under an applied dc magnetic field in order to minimize the probability of quantum tunneling and to evaluate the effect of the dc field on both LF and HF peaks. The relaxation dynamics in $4 a$ (Dy) slows down when the dc field is raised from zero to 2000 Oe (Fig. S9). Above this optimum dc field, as expected, a further increase of the magnetic field accelerates the relaxation process. Therefore, further study of the ac susceptibility as a function of ac frequency has been carried out at 2000 Oe (Fig. 8). It can be seen (Fig. 8, S9) that the form of the $\chi^{\prime \prime}(v)$ isotherms for $\mathbf{4 a}$ is distorted, which is due to clearly occurrence of a second unresolved maximum. The fitting of the ac susceptibility data to the linear combination of two Debye models (Fig. S10, Table S7) allowed us to determine the potential barriers of magnetization reversal, $\Delta_{\text {eff }} / k_{B}=128 \mathrm{~K}$ and $143 \mathrm{~K}$, and the pre-exponential factors, $\tau_{0}=3.0 \cdot 10^{-8} \mathrm{~s}$ and $7.1 \cdot 10^{-8} \mathrm{~s}$ for LF and HF, respectively. It is worth mentioning that the effective anisotropy barrier for $\mathbf{4 a}$ is one of the highest known values for $L n$ carboxylates.

The presence of two maxima on the $\chi^{\prime \prime}(v)$ isotherms was previously reported for monometallic complexes. ${ }^{28,29}$ The theoretical explanation of the appearance of two maxima was carried out previously ${ }^{30}$. Polymorphism can dramatically change the magnetic behavior of $\mathrm{SMM}^{31}$ and may also result in the appearance of the second maxima. Comparable intensities
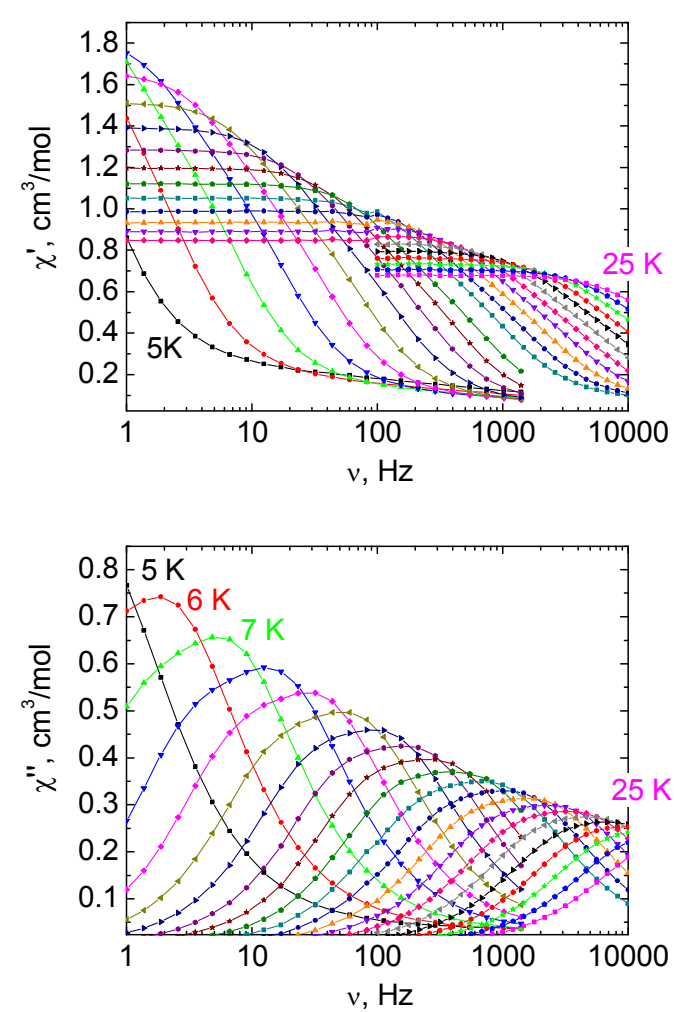

Fig. 8. Frequency dependence of the in-phase $\chi^{\prime}$ (top) and out-of-phase $\chi^{\prime \prime}$ (bottom) components of the ac susceptibility of complex $\mathbf{4 a}$ (Dy) in 2000 Oe dc field (5$25 \mathrm{~K}$, step $1 \mathrm{~K}$ ). Solid lines are visual guides.

of the $\chi$ " signal for both maxima indicate that the quantitative ratio of phases must be near 1:1 if the polymorphism takes place. However, powder X-ray diffraction analysis confirmed the single-phase state of all the compounds under investigation. We can assume that in case of complex $\mathbf{4 a}$ disordering of the water molecules plays crucial role in appearance of two maxima on the $\chi^{\prime \prime}(v)$ dependencies. The appearance of two maxima in systems with coordinated water molecules and/or possible disordering was reported earlier. $^{29 e, j, 1}$

Thus, a study of three mononuclear complexes $\mathbf{3 a}(\mathrm{Tb}), \mathbf{4 a}$ (Dy), and 5a (Ho) has shown that complex 4a (Dy) has the best SMM characteristics, whereas no SMM properties were found for complex 5a (Ho). Interpretations of the properties of lanthanide-containing SMMs should be made with specific features of the electronic structure of lanthanide ions taken into account ${ }^{32}$. Irrespective of the metal type, there are two strict conditions/requirements for a compound to manifest the SMM properties ${ }^{33}$ : bistability of the ground state and magnetic anisotropy. It is expedient to perform directed design of molecular magnets using heavy lanthanide ions: $\operatorname{Tb}^{3+}\left(f^{8}\right.$, ground state $\left.{ }^{7} F_{6}\right), \mathrm{Dy}^{3+}\left(f^{9}\right.$, ground state $\left.{ }^{6} H_{15 / 2}\right), \mathrm{Ho}^{3+}\left(f^{10}\right.$, ground state $\left.{ }^{5} I_{8}\right)$, and $\operatorname{Er}\left(f^{11}\right.$, ground state $\left.{ }^{4} I_{15 / 2}\right)$ due to their 
anisotropy and high spin of the ground state. The three mononuclear complexes under investigation are isostructural. Hence, the crystal field generated by the electron density of the same set of the ligands should be near identical. However, its effect on the attainment of the maximum anisotropy will differ due to differences in the shape of the electron density of the $4 f$-orbitals in cases of $\mathrm{Tb}^{3+}, \mathrm{Dy}^{3+}$ and $\mathrm{Ho}^{3+}$. The behavior of $\mathrm{Tb}^{3+}$ and $\mathrm{Dy}^{3+}$ in isostructural complexes with the same geometry of the coordination environment could be identical. However, $\mathrm{Dy}^{3+}$ is a Kramers ion (i.e., it has an odd number of $f$ electrons). The ground state of such ions is always bistable irrespective of the ligand field symmetry, therefore the requirements for environment symmetry for the $\mathrm{Dy}^{3+}$ ion are less strict. The $\mathrm{Tb}^{3+}$ ion has a higher anisotropy of electron density than $\mathrm{Dy}^{3+}$, but $\mathrm{Tb}^{3+}$ has an even number of $f$-electrons and axial symmetry of the ligand field must be strictly observed. Thus, it may be assumed that the shape of the $\mathrm{Ln}^{3+}$ polyhedron in the mononuclear complexes under study containing chelate ligands is most suitable for reaching the maximum anisotropy for the $\mathrm{Dy}^{3+}$ ion.

In order to evaluate the influence of the disordering of the water molecule hydrogen we performed the electrostatic calculations for mononuclear Dy complex 4a using the electrostatic model for the determination of magnetic anisotropy in dysprosium complexes developed by Chilton et al. ${ }^{34}$ The calculations were carried out using the MAGELLAN program on the basis of charge distribution according to Scheme S1-S3. Previously, in case of mononuclear dysprosium $\beta$-diketonates auxiliary ligands were considered as electroneutral moieties without any localized partial charges ${ }^{34}$. Consideration of water molecules as moieties without partial charges in case of $\mathbf{4 a}$ (Scheme S1) leads to the fact that the anisotropy axis lies in the plane of four $\beta$-diketonate oxygen atoms (see Fig S11). However, taking into account localized partial charges on the water molecules (Scheme S2) results in completely different situation (Fig S12). In this case the anisotropy axis lies in a plane which is perpendicular to the plane of four $\beta$-diketonate oxygen atoms due to the higher negativity of the oxygens of carboxyl groups $(-1 / 2)$ vs. the $\beta$ diketonate oxygen atoms $(-1 / 3)$. Intermediate situation takes place (Fig S13, S14) when the localized partial charge of the water oxygen is comparatively small (e.g., $-1 / 4$, Scheme S3).

We can state that the application of the electrostatic model allowed us to evaluate the influence of the disordering of the water molecule hydrogen in $\mathbf{4 a}$. It can be seen that the difference between the minimal reversal energy values («Min. reversal energy") given by MAGELLAN program is more than $10 \%$ for different positions of the water molecule hydrogen ( $\mathrm{H} 2 \mathrm{~A}$ or $\mathrm{H} 2 \mathrm{~B}$; see Output file information under respective Scheme S2, S3 in S1) which is close to the observed difference in the potential barriers of magnetization reversal in complex $4 a$.

Thus, we can conclude that replacement of the $\beta$ diketonate oxygen donors $(-1 / 3)$ in trans-position with the water molecules by carboxylate oxygen donors $(-1 / 2)$, acac $\rightarrow$ $\mathrm{BcrCO}^{-}$, makes the system much more delicate and therefore further $a b$ initio calculations which will allow to confirm the obtained results are required.

In case of 1D-polymeric complex $\mathbf{3 b}(\mathrm{Tb})$ we observe just non-zero out-of-phase component of ac magnetic susceptibility without clear-cut maxima (Fig. S15) even in nonzero dc field up to 5000 Oe. The lack of maxima on these plots did not allow us to make quantitative estimation of the relaxation barrier height.

The 1D-polymeric complexes of Dy (4b), Er (6) and $\mathrm{Yb}(\mathbf{8})$ demonstrate nearly the same dynamic behavior. Measurements of ac susceptibility for $\mathbf{4 b}, \mathbf{6}$ and $\mathbf{8}$ in zero dc field did not show clear-cut maxima on the $\chi^{\prime \prime}$-frequency plots (Fig. S16, S17). Application of the various external dc magnetic fields allowed us to determine the optimal field of 2000 Oe, wherein the quantum tunneling probability is the lowest (Fig. S18, S19) and the relaxation time is the highest. The increase of the relaxation time values corresponds to a shift of the maximum on the $\chi^{\prime \prime}$-frequency plot towards lower frequencies. The $\chi^{\prime \prime} v s$. $v$ dependences obtained in the optimal magnetic field of 2000 Oe were studied in the $2-10 \mathrm{~K}, 2-7 \mathrm{~K}$ and $2-10 \mathrm{~K}$ temperature ranges for $\mathbf{4 b}$ (Dy) (Fig. S20, Table S8), 6 (Er) (Fig. S21, Table S9) and 8 (Yb) (Fig. S22, Table S10), respectively. We failed to fit the ac susceptibility data for $\mathbf{4 b}$ and 6 by using the single generalized Debye model. Therefore, the $\tau=f(1 / T)$ plots were obtained by the best fit of $\chi^{\prime \prime}$ experimental data to single (for 8) or linear combination of two (for 4b and 6) generalized Debye models (Fig. S23, Fig. S24 and Fig. S25). One can see that at temperatures below $3 \mathrm{~K}$ for 4b (Dy), 6 (Er) and 8 ( $\mathrm{Yb}$ ) quantum tunneling continues to affect the relaxation process considerably even under 2000 Oe magnetic field. An approximation of the $\tau=f(1 / T)$ plots by the Arrhenius equation in the temperature range of $7-10 \mathrm{~K}, 5-$ $7 \mathrm{~K}$ and $5-6.5 \mathrm{~K}$ allowed us to estimate the effective barriers heights as $38 \mathrm{~K}(\mathrm{LF}), 57 \mathrm{~K} / 14 \mathrm{~K}(\mathrm{LF} / \mathrm{HF})$ and $36 \mathrm{~K}$ with the relaxation times $\tau_{0}=6 \cdot 10^{-7} \mathrm{~s}, 1.2 \cdot 10^{-10} \mathrm{~s} / 7.3 \cdot 10^{-7} \mathrm{~s}$ and $1.5 \cdot 10^{-7} \mathrm{~s}$ for $\mathbf{4 b}(\mathrm{Dy}), \mathbf{6}(\mathrm{Er})$ and $\mathbf{8}(\mathrm{Yb})$, respectively.

Apparently, the presence of two maxima on $\chi^{\prime \prime}(v)$ dependences for $\mathbf{4 b}$ and $\mathbf{6}$ has the same nature as in the case of mononuclear Dy complex $\mathbf{4 a}$. Both $\mathbf{4 b}$ and $\mathbf{6}$ complexes contain one coordinated water molecule per Ln ion. Therefore, disordering in the molecular structures is the most probable reason for such phenomenon. In contrast, for $\mathrm{Yb}$ complex (8) only one maximum on $\chi^{\prime \prime}(v)$ was observed. This can be due to the smaller size of $\mathrm{Yb}^{3+}$ which results in more compact molecular packaging.

Thus, it has been shown that among polymeric complexes 3b (Tb), 4b (Dy), 5b (Ho), 6 (Er), 7 (Tm) and 8 (Yb), SMM properties are manifested only by complexes containing Kramers ions (Dy, $\mathrm{Er}$ and $\mathrm{Yb}$ ), whereas complexes containing non-Kramers ions ( $\mathrm{Tb}, \mathrm{Ho}$ and $\mathrm{Tm}$ ) do not exhibit SMM properties.

Moreover, dynamic ac magnetic susceptibility measurements of the mononuclear $\left[\mathrm{Dy}(\mathrm{BcrCOO})(\mathrm{acac})_{2}\left(\mathrm{H}_{2} \mathrm{O}\right)_{2}\right]$ (4a) and 1D-polymeric [Dy $\left.(\mathrm{BcrCOO})(\mathrm{acac})_{2}\left(\mathrm{H}_{2} \mathrm{O}\right)\right]_{\mathrm{n}} \quad$ (4b) complexes have revealed that the presence of more than one $\mathrm{Dy}^{3+}$ in a molecule has an adverse effect on the SMM properties. This is probably due to the fact that, as a rule, SMM 
properties in polynuclear SMM are manifested by each lanthanide atom rather than by the exchange coupled systems as in complexes of $d$-elements. A considerable disadvantage of polynuclear lanthanide complexes (in comparison with similar mononuclear derivatives) lies in the existence of dipole-dipole coupling that accelerates relaxation processes, and in their tendency to quantum tunneling. ${ }^{35}$

\section{Conclusions}

Thus, it has been found that the reactions of benchrotrenecarboxylic acid, $\mathrm{BcrCOOH}$, with hydrated lanthanides acetylacetonates in solvosystems of various compositions afford new heteroleptic benchrotrenecarboxylates, the mononuclear $\left[\mathrm{Ln}(\mathrm{acac})_{2}(\mathrm{BcrCOO})\left(\mathrm{H}_{2} \mathrm{O}\right)_{2}\right](\mathrm{Ln}=\mathrm{Eu}(\mathbf{1}), \mathrm{Gd}(\mathbf{2}), \mathrm{Tb}(\mathbf{3 a}), \mathrm{Dy}(\mathbf{4 a})$, $\mathrm{Ho}(5 \mathrm{a}))$ and the 1D-polymeric $\left[\mathrm{Ln}(\mathrm{acac})_{2}(\mathrm{BcrCOO})\left(\mathrm{H}_{2} \mathrm{O}\right)\right]_{n}(\mathrm{Ln}=$ $\mathrm{Tb}(\mathbf{3 b}), \operatorname{Dy}(\mathbf{4 b}), \mathrm{Ho}(\mathbf{5 b}), \operatorname{Er}(\mathbf{6}), \operatorname{Tm}(\mathbf{7}), \mathrm{Yb}(\mathbf{8}), \mathrm{Y}(\mathbf{9}))$ ones. It appears that the formation of mononuclear complexes is mainly typical for light rare earths elements, whereas formation of 1D-polymeric complexes is more typical for heavy Ln and yttrium. However, a strict position of the «mononuclear complex/1D-polymeric complex» demarcation line/border in the Ln series is determined by the conditions of the synthesis. The structure of complexes $\mathbf{1}, \mathbf{2}, \mathbf{3 a}, \mathbf{4 a}, \mathbf{5 a}$ is built of mononuclear molecules $\left[\mathrm{Ln}(\mathrm{acac})_{2}(\mathrm{BcrCOO})\left(\mathrm{H}_{2} \mathrm{O}\right)_{2}\right.$ ] wherein the $\mathrm{Ln}$ ions are chelated by two $\mathrm{acac}^{-}$and one $\mathrm{BcrCOO}$; two $\mathrm{H}_{2} \mathrm{O}$ molecules complete the coordination environment of the lanthanide. The structure of $1 \mathrm{D}$-polymers $\mathbf{3 b}, \mathbf{4 b}, \mathbf{5 b}, \mathbf{6}-\mathbf{9}$ is built of acetylacetonate moieties $\left\{\operatorname{Ln}(\operatorname{acac})_{2}\left(\mathrm{H}_{2} \mathrm{O}\right)\right\}$, wherein the Ln ions are chelated with acetylacetonate anions, and two bridging benchrotrenecarboxylate groups link the neighbouring $\left\{\mathrm{Ln}(\mathrm{acac})_{2}\left(\mathrm{H}_{2} \mathrm{O}\right)\right\}$ moieties into infinite chains. The ac magnetic susceptibility measurements have shown that mononuclear complexes 3a, $\mathbf{4 a}$ and 1D-polymeric complexes 4b (Dy), 6 (Er) and 8 (Yb) exhibit slow magnetic relaxation, thereby manifesting SMM properties. For $\mathbf{4 a}$, the anisotropy barriers are $\Delta_{\text {eff }} / k_{B}=100 \mathrm{~K}$ and $118 \mathrm{~K}$ in zero dc-field ( $128 \mathrm{~K}$ and $143 \mathrm{~K}$ in $2000 \mathrm{Oe}$ field) for the LF and HF signal respectively. The nature of appearance of two maxima in such type of systems was assigned to disordering of the water molecule hydrogen.

\section{Acknowledgements}

This study was financially supported by the Russian Science Foundation (grant 14-13-00938).

This research was performed using the equipment of the JRC PMR IGIC RAS. We also acknowledge the EPSRC UK National EPR Research Facility and Service at the University of Manchester for support with magnetic measurements.

\section{Appendix A. Supplementary data}

CIF files of the structural data for compounds 1, 2, 3a, 4a, Eu_1D, 4b, 5b, 8 and data collection and structure refinement statistics. CCDC 1519452-1519455 (Eu_1D, 4b, 5b, 8), 1519456-1519459 (1, 2, 3a, 4a). These data can be obtained free of charge from the Cambridge Crystallographic Data Centre via www.ccdc.cam.ac.uk/dat_request/cif.

\section{Notes and references}

1 (a) R. Sessoli and A.K. Powell, Coord. Chem. Rev., 2009, 253, 2328-2341; (b) J.-C. G. Bünzli, J. Coord. Chem., 2014, 67, 3706-3733.

2 (a) G. Castro, M. Regueiro-Figueroa, D. Esteban-Gomez, P. Perez-Lourido, C. Platas-Iglesias and Laura Valencia, Inorg. Chem., 2016, 55, 3490-3497; (b) M. Gregson, N. F. Chilton, A.-M. Ariciu, F. Tuna, I. F. Crowe, W. Lewis, A. J. Blake, D. Collison, E. J. L. McInnes, R. E. P. Winpenny and Stephen T. Liddle, Chem. Sci., 2016, 7, 155-165; (c) F. Pointillart , T. Guizouarn, B. Lefeuvre, S. Golhen, O. Cador and L. Ouahab, Chem. Eur.J., 2015, 21, 16929-16934; (d) N. C. Anastasiadis, D. A. Kalofolias, A. Philippidis, S. Tzani, C. P. Raptopoulou, V. Psycharis, C. J. Milios, A. Escuer and S. P. Perlepes, Dalton Trans., 2015, 44, 10200-10209

3 (a) J.-C. G. Bünzli and C. Piguet, Chem. Soc. Rev., 2005, 34, 1048-1077; (b) P. Bag, A. B. Ghosh, A. K. Dutta, U. Flörke and K. Nag, Polyhedron, 2015, 102, 539-548; (c) M. Ren, Z.-L. Xu, S.-S. Bao, T.-T. Wang, Z.-H. Zheng, R. A. S. Ferreira, L.-M. Zheng and L. D. Carlos, Dalton Trans., 2016, 45, 2974-2982; (d) K. M. N. de Souza, H. J. Batista, M. F. Belian, W. E. Silva, J. A. B. da Silva, J. Luminescence, 2016, 170, 571-587.

4 (a) Q. Xu, Zh. Li, Y. Wang and H. Li, Photochem. Photobiol. Sci., 2016, 15, 405-411; (b) S. V. Eliseeva, J.-C. Bunzli, Chem. Soc. Rev., 2010, 39, 189-227; (c) Ch.-H. Zenga, X.-T. Meng, S.S. Xu, L.-J. Han, S. Zhong and M.-Y. Jia, Sensors and Actuators $B, 2015,221,127-135$.

5 Ch. Huang, Rare earth coordination chemistry: fundamentals and applications, John Wiley \& Sons, Singapore, 2010, 575 p.

6 (a) P. Bag, Ch. Kumar Rastogi, S. Biswas, S. Sivakumar, V. Mereacre and V. Chandrasekhar, Dalton Trans., 2015, 44, 4328-4340; (b) B. Joarder, A. K. Chaudhari, G. Rogez and S. K. Ghos, Dalton Trans., 2012, 41, 7695-7699; (c) D. Aguil, L. A. Barrios, F. Luis, A. Repollies, O. Roubeau, S. J. Teat and G. Arom, Inorg. Chem., 2010, 49, 6784-6786; (d) D. John and W. Urland, Eur. J. Inorg. Chem., 2006, 3503-3509.

7 (a) P. S. Koroteev, Z. V. Dobrokhotova, A. B. Ilyukhin, N. N. Efimov, D. I. Kirdyankin, A. V. Tyurin, Yu. A. Velikodny, M. L. Kovba and V. M. Novotortsev, Polyhedron, 2013, 65, 110121; (b) C.-S. Liu, M. Du, E. C. Sanudo, J. Echeverria, M. Hu, Q. Zhang, L.-M. Zhou and S.-M. Fang, Dalton Trans., 2011, 40, 9366-9369.

8 (a) P. S. Koroteev, Zh. V. Dobrokhotova, A. B. Ilyukhin, N. N. Efimov, D. I. Kirdyankin, A. V. Tyurin, A. V. Gavrikov, V. M. Novotortsev, Polyhedron, 2015, 85, 941-952; (b) J.-P. Costes, J.-M. Clemente Juan, F. Dahan and F. Nicodeme, Dalton Trans., 2003, 1272-1275; (c) M.-F. Wu, M.-S. Wang, S.-P. Guo, F.-K. Zheng, H.-F. Chen, X.-M. Jiang, G.-N. Liu, G.-C. Guo and J.-S. Huang, Cryst. Growth Des., 2011, 11, 372-381; (d) M. Chen, E. Carolina Sañudo, E. Jiménez, S.-M. Fang, C.-S. Liu and M. Du, Inorg. Chem., 2014, 53, 6708-6714.

9 (a) N. Pawlak and G. Oczko, Polyhedron, 2014, 74, 31-38; (b) B. V. Bukvetskii, I. V. Kalinovskaya, A. N. Zadorozhnaya and V.E. Karasev, Russ. J. Inorg. Chem., 2008, 53, 598-603; (c) J.C. Zhuang, D.-D. Zhao, Z.-R. Luo, X.-H. Yin and H.-J. Hao, Synthesis and Reactivity in Inorganic, Metal-Organic, and Nano-Metal Chemistry, 2011, 41, 1208-1214; (d) T. Fiedler, M. Hilder, P. C. Junk, U. H. Kynast, M. M. Lezhnina and M. Warzala, Eur. J. Inorg. Chem., 2007, 291-301.

10 (a) Y.-Y. Yang and W.-T. Wong, Chem. Commun., 2002, 27162717; (b) D. Guo, B.-G. Zhang, C.-Y. Duan, X. Cao and Q.J. 
Meng, Dalton Trans., 2003, 282-284; (c) X. Meng, G. Li, H. Hou, H. Han, Y. Fan, Y. Zhu and Ch. Du, J. Organomet. Chem., 2003, 679, 153-161; (d) D. Guo, Y.-T. Li, C.-Y. Duan, H. Mo and Q.-J. Meng, Inorg. Chem., 2003, 42, 2519-2530; (e) H. Hou, G. Li, L. Li, Y. Zhu, X. Meng and Y. Fan, Inorg. Chem., 2003, 42, 428-435; (f) J. Liu, Y. Li and D. Li, Acta Cryst., 2012. E68, m6-m7; (g) P. S. Koroteev, Zh. V. Dobrokhotova, N. N. Efimov, A. B. Ilyukhin, and V. M. Novotortsev, Rus. J. Coord. Chem., 2014, 40, 495-504.

11 P.F. Yan, F.M. Zhang, G.M Li, J.W. Zhang, W.B. Sun, M. Suda and Y. Einaga, J. Solid State Chem., 2009, 182, 1685-1690.

12 L. Li, J. Li, H. Hou, Y. Fan and Y. Zhu, Inorg. Chim. Acta, 2006, 359, 3139-3146.

13 (a) P. S. Koroteev, M. A. Kiskin, Zh. V. Dobrokhotova, A. M. Bogomyakov, N. N. Efimov, V. M. Novotortsev, Polyhedron, 2011, 30, 2523-2529; (b) P. S. Koroteev, Zh. V. Dobrokhotova, M. A. Kiskin, A. S. Lermontov, N. N. Efimov, A. S. Bogomyakov, A. V. Tyurin, M. A. Bykov, L. I. Demina, Yu. A. Velikodny, S. A. Kozyukhin, V. M. Novotortsev, Polyhedron, 2012, 43, 36-46; (c) P. S. Koroteev, Zh. V. Dobrokhotova, A. B. Ilyukhin, M. S. Motornova, V. M. Novotortsev, Russ. Chem. Bull., 2012, 61, 1069-1078; (d) P. S. Koroteev, N. N. Efimov, Zh. V. Dobrokhotova, A. B. Ilyukhin, A. V. Gavrikov, V. M. Novotortsev, Rus. J. Coord. Chem., 2015, 41, 149-161; (e) A. V. Gavrikov, P. S. Koroteev, Zh. V. Dobrokhotova, A. B. Ilyukhin, N. N. Efimov, D. I. Kirdyankin, M. A. Bykov, M. A. Ryumin, V. M. Novotortsev, Polyhedron, 2015, 102, 48-59; (f) P. S. Koroteev, Zh. V. Dobrokhotova, A. B. Ilyukhin, N. N. Efimov, A. V. Gavrikov and V. M. Novotortsev, Rus. J. Coord. Chem., 2015, 41, 805-816.

14 (a) S. S. Kaye and J. R. Long, J. Am. Chem. Soc., 2008, 130, 806-807; (b) B. Murugesapandian, P. W. Roesky, Dalton Trans., 2010, 39, 9598-9603; (c) B. Murugesapandian, P. W. Roesky, Inorg. Chem., 2011, 50, 1698-1704; (d) B. Murugesapandian and P. W. Roesky, Eur. J. Inorg. Chem., 2011, 4103-4108; (e) B. Murugesapandian and P. W. Roesky, Z. Anorg. Allg. Chem., 2011, 637, 1818-1823.

15 S. Kundu and V. Chandrasekhar, Cryst. Growth Des., 2015, 15, 5437-5450.

16 B. Nicholls, M. C. Whiting, J. Chem. Soc., 1959, 551-556.

17 Bruker, APEX2 and SAINT. Bruker AXS Inc., Madison, Wisconsin, USA, 2007.

18 G.M. Sheldrick, SADABS. University of Göttingen, Germany, 2014.

19 G.M. Sheldrick, TWINABS. University of Göttingen, Germany, 2012.

20 G. Sheldrick, Acta Crystallogr. C, 2015, 71, 3-8.

21 (a) G. B. Deacon, R. J. Phillips, Coord. Chem. Rev., 1980, 33, 227-250; (b) K. Nakamoto, Infrared and Raman Spectra of Inorganic and Coordination Compounds, fourth ed., John Wiley and Sons, New York, 1986.

22 C. Benelli, D. Gatteschi, Chem. Rev., 2002, 102, 2369-2387.

23 (a) L. Thompson, J. Legendziewicz, J. Cybinska, L. Pan and W. Brennessel, J. Alloys Compd., 2002, 341, 312-322; (b) A. Arauzo, A. Lazarescu, S. Shova, E. Bartolomé, R. Cases, J. Luzón, J. Bartolomé and C. Turta, Dalton trans., 2014, 43, 12342-12356; (c) P. S. Koroteev, Z. V Dobrokhotova, A. B. llyukhin, N. N. Efimov, M. Rouzières, M. A. Kiskin, R. Clérac and V. M. Novotortsev, Dalton Trans., 2016, 45, 6405-6417.

24 (a) O. Kahn, Molecular Magnetism, VCH Publishers, Inc., New York, 1993, 380 p; (b) M. Andruh, E. Bakalbassis, Olivier Kahn, J. Ch. Trombe and P. Porchers, Inorg. Chem., 1993, 32, 1616-1622.

25 P. Caro and P. Porcher, J. Magn. Magn. Mater., 1986, 58, 6166.

26 X.-J. Wang, Z.-M. Cen, Q.-L. Ni, X.-F. Jiang, H.-C. Lian, L.-C. Gui, H.-H. Zuo and Z.-Y. Wang, Crystal Growth Des., 2010, 10, 2960-2968.
27 N.F. Chilton, R.P. Anderson, L.D. Turner, A. Soncini and K.S. Murray, J. Comput. Chem., 2013, 34, 1164-1175.

28 (a) D. Pinkowicz, M. Ren, L.-M. Zheng, S. Sato, M. Hasegawa, M. Morimoto, M. Irie, B.K. Breedlove, G. Cosquer, K. Katoh and M. Yamashita, Chem. Eur. J., 2014, 20, 12502 - 12513; (b) J. D. Rinehart, K. R. Meihaus and J. R. Long, J. Am. Chem. Soc., 2010, 132, 7572-7573.

29 (a) M. Gregson, N. F. Chilton, A.-M. Ariciu, F. Tuna, I. Crowe, W. Lewis, A. J. Blake, D. Collison, E. J. L. Mclnnes, R. E. P. Winpenny and S. Liddle, Chem. Sci., 2015, 7, 155-165; (b) S. K. Gupta, T. Rajeshkumar, G. Rajaraman and R. Murugavel, Chem. Commun., 2016, 52, 7168-7171; (c) F. Habib, I. Korobkov and M. Murugesu, Dalton Trans., 2015, 44, 636873; (d) F. Habib, O. R. Luca, V. Vieru, M. Shiddiq, I. Korobkov, S. I. Gorelsky, M. K. Takase, L. F. Chibotaru, S. Hill, R. H. Crabtree and M. Murugesu, Angew. Chem., Int. Ed., 2013, 52, 11290-11293; (e) R. J. Holmberg, L. T. A. Ho, L. Ungur, I. Korobkov, L. F. Chibotaru and M. Murugesu, Dalton. Trans., 2015, 44, 20321-20325; (f) M. Jeletic, P. H. Lin, J. J. Le Roy, I. Korobkov, S. I. Gorelsky and M. Murugesu, J. Am. Chem. Soc. 2011, 133, 19286-19289; $(g)$ J. Li, Y. Han, F. Cao, R.-M. Wei, Y.-Q. Zhang and Y. Song, Dalton Trans., 2016, 45, 9279-9284; (h) E. Lucaccini, M. Briganti, M. Perfetti, L. Vendier, J. P. Costes, F. Totti, R. Sessoli and L. Sorace, Chem. Eur. J., 2016, 22, 5552-5562; (i) J. Miklovič, D. Valigura, R. Boča and J. Titiš, Dalton Trans., 2015, 44, 12484-12487; (j) J. Ruiz, A. J. Mota, A. Rodríguez-Diéguez, S. Titos, J. M. Herrera, E. Ruiz, E. Cremades, J. P. Costes and E. Colacio, Chem. Commun., 2012, 48, 7916-8016; (k) G. Cosquer, F. Pointillart, S. Golhen, O. Cador and L. Ouahab, Chem. Eur. J., 2013, 19, 7895-7903; (I) M. Ren, D. Pinkowicz, M. Yoon, K. Kim, L.-M. Zheng, B.K. Breedlove and M. Yamashita, Inorg. Chem., 2013, 52, 83428348.

30 L. T. A. Ho and L. F. Chibotaru, Phys. Rev. B, 2016, 94, 104422-1-5.

31 A. A. Pavlov, Y. V. Nelyubina, S. V. Kats, L. V. Penkova, N. N. Efimov, A. O. Dmitrienko, A. V. Vologzhanina, A. S. Belov, Y. Z. Voloshin and V. V Novikov, J. Phys. Chem. Lett., 2016, 7, 4111-4116.

32 J. D. Rinehart and J. R. Long, Chem. Sci., 2011, 2, 2078-2085.

33 D. N. Woodruff, R. E. P. Winpenny and R. A. Layfield, Chem. Rev., 2013, 113, 5110-5148.

34 N. F. Chilton, D. Collison, E. J. L. McInnes, R. E. P. Winpenny and A. Soncini, Nat. Commun., 2013, 4, 2551-1-7.

35 N. N. Efimov, P. S. Koroteev, A. V. Gavrikov, A. B. Ilyukhin, Zh. V. Dobrokhotova and V. M. Novotortsev, Magnetochemistry, 2016, 2, 38 (15 p). 


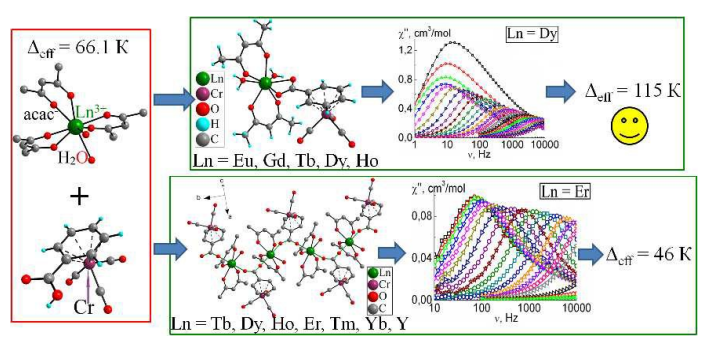

Novel derivatives of lanthanides and $\left(\eta^{6}\right.$-benzoic acid)tricarbonylchromium were synthesized and characterized; complexes of Tb, Dy, Er, Yb exhibit SMM behavior. 